\title{
Tellurium behaviour in a major European fluvial-estuarine system (Gironde, France): fluxes, solid/liquid partitioning and bioaccumulation in wild oysters
}

\author{
Gil-Díaz Teba ${ }^{1}$, Schäfer Jörg 1, *, Dutruch Lionel ${ }^{1}$, Bossy Cécile ${ }^{1}$, Pougnet Frédérique ${ }^{1}$, \\ Abdou Melina ${ }^{1}$, Lerat-Hardy Antoine ${ }^{1}$, Pereto Clément ${ }^{1}$, Derriennic Hervé ${ }^{1}$, Briant Nicolas ${ }^{2}$, \\ Sireau Teddy ${ }^{2}$, Knoery Joel ${ }^{2}$, Blanc Gerard ${ }^{1}$
}

1 Université de Bordeaux, UMR CNRS 5805 EPOC, Allée Geoffroy Saint-Hilaire, 33615 Pessac, France

2 IFREMER - RBE/BE/Laboratoire de Biogéochimie des Contaminants Métalliques, BP 21105, Nantes

F-44311, France

*Corresponding author : Jörg Schäfer, email address : jorg.schafer@u-bordeaux.fr

\begin{abstract}
:
Tellurium (Te) is a technology critical element (TCE) with largely unknown environmental behaviour, especially in continent-ocean interface systems. The unknown behaviour results from the lack of studies in aquatic environments and from analytical challenges limiting the determination of its naturally low (ultratrace) environmental levels. We performed a comprehensive study of Te in the Lot-Garonne-Gironde fluvial-estuarine system to better understand seasonal variations, solid/liquid partitioning (Kd), gross fluxes, estuarine dynamics, and transfer to wild oysters at the estuary mouth. A temporal record (20142017) of dissolved (Ted) and particulate (Tep) Te concentrations at five sites in the Lot-Garonne River system shows little differences between sites, with average $\sim 0.9 \mathrm{ng} \mathrm{L}-1$ and $\sim 50 \mu \mathrm{g} \mathrm{kg}-1$ respective concentrations. Watershed Ted and Tep follow parallel seasonal patterns, which result in constant partitioning ( $\log 10 \mathrm{Kd} \sim 4.75 \mathrm{~L} \mathrm{~kg}-1)$, with constant annual gross dissolved fluxes $(\sim 15.0 \mathrm{~kg} \mathrm{y}-1)$ and variable gross particulate fluxes (from 6.50 to $140 \mathrm{~kg} \mathrm{y}-1$ ) entering the Gironde Estuary. Estuarine reactivity in contrasting hydrological conditions (from flood to drought) suggest that grain-size effects and/or estuarine hydrological residence times strongly affect Tep behaviour. Historical records (19842017) of Te in wild oysters at the estuary mouth vary from 1.33 to $2.89 \mu \mathrm{g} \mathrm{kg}-1$ dry weight (d.w.), without any clear long-term trend. This study provides rare knowledge on Te environmental dynamics in aquatic systems, and suggests that, although no current anthropogenic sources were identified in the economically developed Lot-Garonne-Gironde fluvial-estuarine system, there is a non-negligible bioaccumulation in wild oysters at the estuary mouth.
\end{abstract}

Keywords : Garonne River, Gironde Estuary, Lot River, RNO/ROCCH, technology critical element. 


\section{Introduction}

Tellurium (Te) is a chalcophile metalloid with numerous applications in medicine and other fields due to its thermoelectric, catalytic and photonic properties (Wang and Guan 2012). Worldwide, the relative contributions of main applications are (USGS 2018): (i) 15\% as additive for improving machinability of steel and iron, or for modifying physical characteristics of non-ferrous alloys like aluminium, tin, copper, lead, magnesium, and manganese, (ii) $30 \%$ in thermoelectric materials (e.g. as $\mathrm{Bi}_{2} \mathrm{Te}_{3}$ and $\mathrm{PbTe}$; Chen et al. 2014, Zhou et al. 2014), and (iii) $40 \%$ in photonics (e.g., as rare earthdoped tellurite glasses, as CdTe in photovoltaics or as quantum dots for telecommunications, photodetectors and biotechnologies; Turner et al. 2012, Leal et al. 2015, Mahdy et al. 2015).

The use of Te in the thin-film solar panel industry classifies Te within the Technology Critical Elements (TCE), as its low lithological, crustal abundances (average $\sim 2 \mu \mathrm{g} \mathrm{kg}^{-1}$; Salminen et al. 2005, Kabata-Pendias, 2011) and the fact that it is extracted as a by-product from copper and lead refineries (USGS 2018) imply the risk of Te shortcuts in view of future socioeconomic demands (Cobelo-García et al. 2015). Increasing and diverse uses can potentially release Te to the environment as an emerging contaminant (despite little environmental evidence; Biver and Filella 2016, Filella and RodríguezMurillo 2017). Nevertheless, Te is listed among the European water pollution priority substances (Directive 2006/11/EC) due to its potential high toxicity for both organisms and humans (Schroeder et al. 1967).

Little is known about Te cycling and its biogeochemical behaviour in environmental compartments, especially in aquatic environments (Belzile and Chen 2015). This is mainly related to analytical challenges as dissolved concentrations are within the $\mathrm{ng} \mathrm{L}^{-1}$ range (e.g., median of $2.5 \mathrm{ng} \mathrm{L}^{-1}$ and maximum values of $\sim 110 \mathrm{ng} \mathrm{L}^{-1}$ in European streams; Salminen et al. 2005). However, there is little information on $\mathrm{Te}$ behaviour in freshwater suspended sediments, let alone temporal trends or seasonality. Furthermore, seawater Te concentrations are poorly constrained as published concentrations until now range between 0.08 and $910 \mathrm{ng} \mathrm{L}^{-1}$, apparently independent from the pre-concentration and pre-reduction steps needed according to the analytical method, with no published data $<1 \mathrm{ng} \mathrm{L}^{-1}$ since 1990 (Filella 2013, Biver et al. 2015). This contrasts with its known strong particle affinity (Whitehead et al. 1988, Wu et al. 2014), with particulate Te concentrations ranging between $<5-880 \mu \mathrm{g} \mathrm{kg}^{-1}$ in marine sediments (Belzile and Chen 2015). In fact, open ocean vertical profiles support that Te behaves as a scavenged element, with $\mathrm{Te}(\mathrm{VI})$ being the dominant species (Lee and Edmond 1985, Yoon et al. 1990, Wu et al. 2014). However, little is known about estuarine environments, as there are only three case studies on dissolved Te (van der Sloot et al. 1985, Wu et al. 2014) and particulate Te (Duan et al. 2014a) reactivity along salinity gradients. Although there is no proof of Te being a biologically essential element (Chasteen et al. 2009, Ba et al. 2010), it seems to be assimilated by plants (e.g. Yang et al. 2014) 
and aquatic organisms, showing average $\sim 12 \mu \mathrm{g} \mathrm{kg}^{-1}$ fresh weight (f.w.) in oysters and 2-3 $\mu \mathrm{g} \mathrm{kg}^{-1}$ f.w. in shellfish from French markets and food consumption surveys (Guérin et al. 2011, Millour et al. 2012).

The aim of this study is to provide a comprehensive view of Te biogeochemical behaviour in transition waters of the Lot-Garonne-Gironde fluvial-estuarine system. For this, a recent 4-year record (2014-2017) on dissolved and suspended particulate Te monitoring at five selected sampling points along the Lot-Garonne watershed was performed to assess Te dynamics (i.e., seasonal behaviour, solid/liquid partitioning, enrichment factors and gross fluxes). In addition, sampling campaigns (20142017) along the salinity and turbidity gradients of the Gironde Estuary aim at providing insights in estuarine Te reactivity in different hydrological conditions (from low to high discharge conditions). Finally, Te accumulation in wild oysters of the estuary mouth (La Fosse) from the French National Mussel Watch Program (RNO/ROCCH) are studied to evaluate potential Te transfer to seafood.

\section{Experimental}

\subsection{Study Area}

\subsubsection{The Lot-Garonne-Gironde fluvial estuarine system}

The Lot River watershed is known for historical metal pollution $(\mathrm{Cd}, \mathrm{Pb}, \mathrm{Cu}, \mathrm{Hg})$ from former mining and $\mathrm{Zn}-\mathrm{Cu}$ smelting activities (1842 to 1987), due to accidental events and long-term lixiviation of openair waste disposals/tailings from the area of Decazeville (Audry et al. 2004). This historical multi-metal pollution and ongoing decontamination due to remediation works have produced contrasting geochemical signals in the hydroelectric lake sediments along the Lot River (e.g., $\mathrm{Ag}, \mathrm{Cd}, \mathrm{Cu}, \mathrm{Zn}, \mathrm{Pb}$, Hg; Audry et al. 2004, Lanceleur et al. 2011a,b) upstream (geochemical background; Marcenac site) and downstream (Cajarc site) of the confluence of the Lot River and the Riou Mort River, draining the former industrial area (Figure 1). The accompanying long-term decontamination monitoring program at five sites along the Riou Mort-Lot-Garonne River continuum to the estuarine freshwater reaches (La Réole site; Figure 1) has enabled several long-term studies on biogeochemical dynamics of trace elements at the watershed scale (e.g., Ag, Sb, Gd; Lanceleur et al. 2011a, Gil-Díaz et al. 2018, LeratHardy et al. 2019). The different sites are: (1) "Boisse Penchot" (BP) on the upstream Lot River, (2) "Riou Mort" (RM) at the outlet of the Riou Mort River watershed hosting the identified industrial point sources, (3) "Temple" (T), at the outlet of the Lot River watershed, (4) "Port-Sainte-Marie" (PSM) on the upstream Garonne River (i.e. representative of influences from the city of Toulouse and the Pyrenean mountains) and (5) "La Réole" (LR), on the downstream Garonne River, at the upper limit of tidal influence, i.e., the main fluvial input to the Gironde Estuary.

The Gironde Estuary constitutes an important continent-ocean interface system, being one of the largest estuaries in Europe, located on the Atlantic Coast in the SW of France (Figure 1). The Gironde 
Estuary drains the Garonne and the Dordogne River watersheds with a total area of approximately 81 $000 \mathrm{~km}^{2}$ (Salomon 2002, Schäfer et al. 2002) hosting important urban/industrial hot-spots (mainly the cities of Bordeaux and Toulouse), extensive vineyard surfaces (up to $12 \%$ of the Aquitaine territorial surface in 2011; www.gironde-tourisme.fr), natural and timber forests (up to $50 \%$ of the territory in 2011; www.gironde-tourisme.fr) and punctual, scattered solar electrical power installations, especially along the Garonne River (http://www.solarenergymaps.com/Europe.html\#.WQdnc9w6_IU).

The estuary receives an average freshwater discharge (Q) of $\sim 1000 \mathrm{~m}^{3} \mathrm{~s}^{-1}$ ( $\sim 64 \%$ from the Garonne River; DIREN) and features a semi-diurnal tide (cycles of $12 \mathrm{~h} 25 \mathrm{~min}$ ) which extends $180 \mathrm{~km}$ upstream from the estuary mouth (up to La Réole). Average water residence times vary from 86 days in low discharge conditions to 18 days in high discharge (Castaing and Jouanneau 1979, Jouanneau and Latouche 1981). Suspended Particulate Matter (SPM) has an average residence time of 1-2 years, forming a strong Maximum Turbidity Zone (MTZ of > $1000 \mathrm{mg} \mathrm{L}^{-1}$; Castaing and Jouanneau 1979, Sottolichio and Castaing 1999). Coastal expulsion of the MTZ needs continuous high river discharge over a long period, displacing the MTZ towards the estuarine mouth, and a strong tidal coefficient (> 85, spring tides), so that ebb conditions can drag the MTZ seawards (Allen et al. 1980, Castaing and Allen 1981, Doxaran et al. 2009).

The Gironde Estuary mouth hosts wild oysters at the La Fosse site (Figure 1) being part of the National Network for the Observation of Marine Environment Quality (RNO/ROCCH; i.e. the French Mussel-Watch; http://www.ifremer.fr/deltn/pages/rno.htm). This programme has sampled, analysed and stored total soft tissues of wild-growing Japanese oysters (Crassostrea gigas, cf. Magallana gigas) and mussels (Mytilus edulis and Mytilus galloprovincialis) since 1979 initially reflecting the historical metal (Cd) contamination derived from the Lot River (http://www.ifremer.fr/deltn/pages/rno.htm). As a result, proper oyster production in the estuary has been banned and metals exported from the Gironde Estuary to the coastal ocean can reach the Marennes-Oléron Bay, one of the most important oyster production zones in Europe (Latouche 1992).

\subsection{Sampling strategy}

\subsubsection{Water and particles}

Water and SPM samples were collected manually using similar protocols for both watershed monitoring sites ( monthly frequency from 2014 to $2017: \mathrm{N}=64$ at $\mathrm{LR}, \mathrm{N}=62$ at PSM, N = 62 at T, $\mathrm{N}=63$ at $\mathrm{BP}, \mathrm{N}=62$ at $\mathrm{RM}$ ) and estuarine longitudinal sampling campaigns named MGTS for "Métaux Gironde Transfert et Spéciation" (N = 26 for MGTS I in March 2014, N = 23 for MGTS II in March 2015, N = 26 for MGTS III in October 2015 and N = 20 for MGTS IV in June 2017). The latter were performed along the estuarine salinity gradient from Bordeaux to the estuary mouth on board the R/V 
Thalia (IFREMER) during four different hydrological situations covering a wide range of freshwater discharges $\left(\mathrm{Q}_{\text {MGTS I }}=1203 \mathrm{~m}^{3} \mathrm{~s}^{-1}\right.$; Q $_{\text {MGTS II }}=3450 \mathrm{~m}^{3} \mathrm{~s}^{-1}$; Q MGTS III $=206 \mathrm{~m}^{3} \mathrm{~s}^{-1}$, Gil-Díaz et al. 2016, $\left.\mathrm{Q}_{\text {MGTS IV }}=235 \mathrm{~m}^{3} \mathrm{~s}^{-1}\right)$.

Sub-surface water was sampled with a telescopic arm ( $\sim 0.3 \mathrm{~m}$ depth, $1 \mathrm{~m}$ from the river bank) or a Niskin bottle (on-board at $1 \mathrm{~m}$ depth), using acid-washed polypropylene (PP) bottles, previously rinsed with water from the site. The samples were immediately filtered on-site through $0.2 \mu \mathrm{m}$ Minisart ${ }^{\circledR}$ cellulose acetate filters into acid-washed polypropylene (PP) bottles, acidified with $\mathrm{HNO}_{3}(1 / 1000 \mathrm{v} / \mathrm{v}$; J.T. Baker ultrapure, $14 \mathrm{M}$ ) and stored at $4^{\circ} \mathrm{C}$ in the dark pending analysis. At the same time, SPM samples were collected into $40 \mathrm{~L}$ acid-washed polyethylene (PE) drums, previously rinsed with water from the site. Particles were retrieved by centrifugation (Westfalia, $12000 \mathrm{~g}$; Lapaquellerie et al. 1996), oven-dried $\left(50^{\circ} \mathrm{C}\right)$, ground and homogenised (agate mortar), then stored at room temperature in the dark until analysis.

\subsubsection{Biological material (wild oysters)}

The RNO/ROOCH program (IFREMER) collects on a regular basis two-year old ( $\sim 8 \mathrm{~cm}$ long) wild oysters Crassostrea gigas (cf. Magallana gigas) during winter (February-March) at the La Fosse (Figure 1) according to the guidelines for monitoring contaminants in biota (OSPAR commission; http://www.ospar.org). After depuration with particle-free water from the site, whole soft bodies are dissected, pooled (20-60 individuals, depending on size), ground, freeze-dried and homogenised, and stored in the National Mussel watch sample bank pending Te analyses. For this study, oyster samples were extracted from the sample bank covering the period from 1984 to $2017(\mathrm{~N}=18)$, with 2-year intervals.

\subsubsection{Suspended particulate matter (SPM) concentrations and physico-chemical parameters}

Precise volumes of water were filtered in situ through dry pre-weighed filters (Xilab glass microfiber, $0.7 \mu \mathrm{m}$ ) for quantification of SPM concentrations. Filters were then dried to constant weight at $50^{\circ} \mathrm{C}$ and re-weighed. Physical-chemical parameters such as water temperature and conductivity (TetraCon $96{ }^{\circledR}$ probe, PROFILINE, WTW), pH (Sentix ® 41 probe, PROFILINE, WTW) and redox potential of the water (Eh, PH-25 CRISON® probe) were measured in situ. 


\subsection{Sample treatment and Te quantification}

\subsubsection{Dissolved Te $\left(\mathrm{Te}_{\mathrm{d}}\right)$}

Only freshwater samples were analysed for $\mathrm{Te}_{\mathrm{d}}$ in this study due analytical limitations in seawater samples (matrix effects and low expected concentrations). Freshwater was directly analysed by external calibration with triple quadrupole ICP-MS (iCAP-TQ, THERMO®) in Kinetic Energy Discrimination KED-mode (He). Only $\mathrm{m} / \mathrm{z}{ }^{125} \mathrm{Te}$ was used for total dissolved $\mathrm{Te}\left(\mathrm{Te}_{\mathrm{d}}\right)$ quantification due to important and variable interferences such as ${ }^{126} \mathrm{Xe}(16-80 \%),{ }^{110} \mathrm{Cd}{ }^{16} \mathrm{O}\left(\sim 50 \%\right.$ in Riou Mort samples), ${ }^{110} \mathrm{Pd}^{16} \mathrm{O}$ $(5-25 \%)$ and ${ }^{86} \mathrm{Sr}^{40} \mathrm{Ar}(10-40 \%)$ on ${ }^{126} \mathrm{Te}$ (Filella and Rodushkin 2018). Polyatomic interferences on ${ }^{125} \mathrm{Te}$ were $<0.1 \%$ (i.e., ${ }^{109} \mathrm{Ag}^{16} \mathrm{O}$ and ${ }^{107} \mathrm{Ag}^{18} \mathrm{O}$, none observed for ${ }^{89} \mathrm{Y}^{36} \mathrm{Ar}$; Filella and Rodushkin 2018). Detection limits (LOD) were $0.09 \pm 0.05 \mathrm{ng} \mathrm{L}^{-1}\left(\mathrm{~N}=14\right.$ analyses of 10 blanks of $2 \% \mathrm{HNO}_{3}$ J.T. Baker ultrapure) and recoveries from freshwater Certified Reference Materials (CRM NIST 1643f, N = 76) were $92 \pm 14 \%$.

\subsubsection{Particulate $\mathrm{Te}\left(\mathrm{Te}_{\mathrm{p}}\right)$}

Representative aliquots of SPM (i.e., $\sim 30 \mathrm{mg}$ ) were digested in acid-cleaned closed PP tubes (DigiTUBEs ${ }^{\circledR}$, SCP SCIENCE) in a Teflon ${ }^{\circledR}$-coated heating block $\left(2 \mathrm{~h}\right.$ at $110{ }^{\circ} \mathrm{C}$; SCP Science) with $1.5 \mathrm{ml} \mathrm{HCl}$ (10 M Suprapur®, Merck), $750 \mu \mathrm{HNO}_{3}$ (14 M Suprapur®, Merck) and $2.5 \mathrm{ml} \mathrm{HF}$ (29 M Suprapur®, Fisher), as described elsewhere (Schäfer et al. 2002, Gil-Díaz et al. 2018). After evaporation to dryness and re-dissolution of the residue with $250 \mu \mathrm{HNO}_{3}(14 \mathrm{M})$ in the heating block, the samples were completed to $10 \mathrm{ml}$ using Milli-Q water.

Concentrations of particulate $\mathrm{Te}\left(\mathrm{Te}_{\mathrm{p}}\right)$ were quantified by triple quadrupole ICP-MS (iCAP-TQ, THERMO®) in KED-mode (He) using external calibration. In this case, ${ }^{125} \mathrm{Te} \mathrm{m} / \mathrm{z}$ was highly interfered compared to ${ }^{126} \mathrm{Te}$, not related to ${ }^{90} \mathrm{Zr}^{35} \mathrm{Cl}(<1 \%),{ }^{88} \mathrm{Sr}^{37} \mathrm{Cl}(<1 \%),{ }^{109} \mathrm{Ag}^{16} \mathrm{O}(<1 \%),{ }^{89} \mathrm{Y}^{36} \mathrm{Ar}(<1 \%)$ nor ${ }^{85} \mathrm{Rb}^{40} \mathrm{Ar}$ (low blanks), potentially suggesting non-negligible roles of other not yet identified polyatomic interferences (e.g., ${ }^{39} \mathrm{~K}^{86} \mathrm{Sr},{ }^{56} \mathrm{Fe}^{69} \mathrm{Ga}$ and others) doubling ${ }^{125} \mathrm{Te}$ signal compared to the expected ${ }^{125} \mathrm{Te} /{ }^{126} \mathrm{Te}$ natural ratio. Therefore, natural Te was quantified from ${ }^{126} \mathrm{Te}$ correcting for ${ }^{126} \mathrm{Xe}$ (generally $<12 \%),{ }^{86} \mathrm{Sr}^{40} \mathrm{Ar}$ (generally $<7 \%$ ), ${ }^{110} \mathrm{Cd}{ }^{16} \mathrm{O}$ (generally <6\%) and ${ }^{110} \mathrm{Pd}^{16} \mathrm{O}$ (generally $<2 \%$ ) interferences estimated from independent respective monoelemental solutions and analytical blanks $\left(2 \% \mathrm{HNO}_{3}\right)$. Quality monitoring was performed using two CRM: freshwater NIST 1643f (for ICP-MS calibration performance, N=29) and stream sediment NCS DC 73307 (for digestion performance, N=36). Results show good recoveries of $96 \pm 3 \%$ in NIST $1643 \mathrm{f}$ and values consistently within the range of certified concentrations for stream sediment NCS DC 73307 (i.e., between $25.3-32.5 \mu \mathrm{g} \mathrm{kg}^{-1}$ for a certified value of $41 \pm 15 \mu \mathrm{g} \mathrm{kg}^{-1}$ ), and a limit of detection (LOD) of $0.42 \pm 0.17 \mathrm{ng} \mathrm{L}^{-1}(\mathrm{~N}=80)$. Complementary, 
thorium (Th) was also measured for grain-size correction purposes (i.e., recoveries of $90 \%$ in marine sediment NIST SRM 2702, N=12, and 85\% for NIST® RM 8704, N=36).

\subsubsection{Te in biological material}

Aliquots of $\sim 200 \mathrm{mg}$ of freeze-dried oyster tissues from the RNO/ROCCH sample bank were digested with $4 \mathrm{~mL} \mathrm{HCl} \mathrm{(34-37 \%} \mathrm{Suprapur®,} \mathrm{SCP} \mathrm{Science)} \mathrm{and} 2.8$ mL HNO 3 (67-69\% Suprapur®, SCP Science) in a microwave-assisted oven (ETHOS UP, Milestone Srl). The temperature program was set at $9^{\circ} \mathrm{C} \mathrm{min}^{-1}$ to $180^{\circ} \mathrm{C}$, followed by $30 \mathrm{~min}$ at $180^{\circ} \mathrm{C}$ before cooling down. These acid digestions were brought to a final $25 \mathrm{~mL}$ volume with Milli-Q water (Daskalakis et al. 1997, USEPA Method 6020A). However, due to important interferences on ${ }^{125} \mathrm{Te}\left(\sim 30 \%\right.$ for $\mathrm{AgO}$ and $\sim 60 \%$ for $\left.{ }^{90} \mathrm{Sr}^{35} \mathrm{Cl}\right)$ and ${ }^{126} \mathrm{Te}(2 \%$ for ${ }^{126} \mathrm{Xe}, 1-4 \%$ for ${ }^{110} \mathrm{Pd}^{16} \mathrm{O}, 1-11 \%$ for ${ }^{86} \mathrm{Sr}^{40} \mathrm{Ar}$ and most importantly $\sim 80 \%$ for ${ }^{110} \mathrm{Cd}^{16} \mathrm{O}$, high $\mathrm{Cd}$ concentrations in oysters due to historical pollution in the Gironde Estuary), sample aliquots were evaporated at $50-60^{\circ} \mathrm{C}$ and recovered in $\mathrm{HNO}_{3}$ matrix. After this treatment, only ${ }^{125} \mathrm{Te}$ was used to quantify Te content in oyster tissues, taking into account the interferences of ${ }^{90} \mathrm{Sr}^{35} \mathrm{Cl}$ (now <4\%) and $\mathrm{AgO}(\sim 30-40 \%)$ corresponding to $12-21 \%$ variability in Te quantification.

Like with $\mathrm{Te}_{\mathrm{p}}$, biological Te was determined by triple quadrupole ICP-MS (iCAP-TQ, THERMO®) in KED-mode (He) using external calibration. In all cases, digestion blanks $(\mathrm{N}=3$ per digestion batch) were used to control any contamination from the digestion processes $\left(<1 \mathrm{ng} \mathrm{L}^{-1}\right.$ for LOD of $0.02 \mathrm{ng} \mathrm{L}$ ${ }^{1}, \mathrm{~N}=10$ ). As there is no CRM for Te in biological materials, only reproducibility was monitored using a CRM used for complementary elements like Sb, Sn and Se (NIST Oyster Tissue 1566b) showing $\sim 15 \%$ relative standard deviations (RSD) in microwave assisted digestions $\left(3.20 \pm 0.52 \mu \mathrm{g} \mathrm{kg}^{-1}, \mathrm{~N}=11\right)$.

\subsection{Modified geoaccumulation index $\left(I^{\prime}\right.$ geo $)$}

The modified geoaccumulation index ( $\mathrm{I}_{\text {geo }}$, Equation 1) introduced by Lee et al. (2008), based on the original index by Müller (1969), describes the degree of contamination of a sample and the potential grain size effect $\left(\mathrm{M}_{\mathrm{z}}\right)$ on trace element concentrations at different sites $(s)$ by normalizing the concentration $\left(\mathrm{C}_{s}\right)$ of the examined element $(\mathrm{Xi})$ at site $s$ to the geochemical background $\left(\mathrm{B}_{s}\right)$ of $\mathrm{Xi}$ $\left(\mathrm{C}_{\mathrm{s}} / \mathrm{B}_{\mathrm{s}}\right)$. Given the highly variable transport energy and hence particle sizes transported in river systems, we decided to use this modified I' ${ }_{\text {geo }}$ :

$$
\mathrm{I}_{\text {geo }}^{\prime}=\log _{2}\left(\mathrm{C}_{s} /\left(1.5 \cdot \mathrm{B}_{s} \cdot \mathrm{M}_{\mathrm{z}}\right)\right)
$$

where 1.5 is a factor to account for background variations in the environment or small anthropogenic influences (Müller 1969) and $M_{z}$ refers to $M_{z C} / M_{z B}$ which is a proxy of the grain size ratio at the studied site $\left(\mathrm{M}_{\mathrm{zC}}\right)$ compared to the reference area $\left(\mathrm{M}_{\mathrm{zB}}\right)$. This $\mathrm{I}_{\text {geo }}$ index classifies soils/sediments into five 
categories: class 1 ( $\mathrm{I}_{\text {geo }}^{\prime}<1$, unpolluted to moderately polluted), class $2\left(1 \leq \mathrm{I}_{\text {geo }}^{\prime}<2\right.$, moderately polluted), class 3 ( $2 \leq \mathrm{I}_{\text {geo }}^{\prime}<3$, moderately to strongly polluted), class $4\left(3 \leq \mathrm{I}_{\text {geo }}<4\right.$, strongly polluted), and class 5 ( $I_{\text {geo }}^{\prime} \geq 4$, strongly to very strongly polluted).

In the Garonne-Gironde fluvial-estuarine system, Th is used as an adequate normalizing element to correct grain size effects (Krachler and Shotyk 2004, Larrose et al. 2010). Accordingly, we have calculated $\mathrm{I}_{\text {geo }}$ (Equation 2) using $\mathrm{Th}_{\mathrm{p}}$-normalised $\mathrm{Te}_{\mathrm{p}}$.

$$
\mathrm{I}_{\text {geo }}^{\prime}=\log _{2}\left(\frac{\left(\frac{\mathrm{Te}}{\mathrm{Th}}\right)_{s}}{1.5 \cdot\left(\frac{\mathrm{Te} p}{\mathrm{Th} p}\right)_{\mathrm{ref}}}\right)
$$

where the average of $\mathrm{Te}_{\mathrm{p}} / \mathrm{Th}_{\mathrm{p}}=4 \cdot 2 \cdot 10^{-3}$ present in the Marcenac core (Gil-Díaz et al., unpublished) is used as reference $\left(\mathrm{Te}_{\mathrm{p}} / \mathrm{Th}_{\mathrm{p}}\right)_{\text {ref }}$ for the regional natural geochemical background.

\subsection{Distribution coefficient $(\mathrm{Kd})$}

Tellurium partitioning between dissolved and particulate concentrations can be described by the particle-water distribution coefficient (Kd; Sung 1995). Briefly, $\mathrm{Kd}\left(\mathrm{in} \mathrm{L} \mathrm{kg}{ }^{-1}\right)$ is the particulate $\left(\mathrm{mg} \mathrm{kg}^{-}\right.$ $\left.{ }^{1}\right)$ to dissolved $\left(\mathrm{mg} \mathrm{L}^{-1}\right)$ concentration ratio (Equation 3). Total $\mathrm{Te}\left(\mathrm{Te}_{\mathrm{T}}\right.$, Equation 4) can be described as the sum of both $\mathrm{Te}_{\mathrm{d}}$ and $\mathrm{Te}_{\mathrm{p}}$. Both equations can be combined to describe the relationship between the particulate fraction of $\mathrm{Te}(\%)$ and $\mathrm{Kd}$ (Equation 5).

$$
\begin{gathered}
\mathrm{K}_{\mathrm{d}}=\mathrm{Te}_{\mathrm{p}} / \mathrm{Te}_{\mathrm{d}} \\
\mathrm{Te}_{\mathrm{T}}=\mathrm{Te}_{\mathrm{p}} \cdot \mathrm{SPM}+\mathrm{Te}_{\mathrm{d}} \\
\mathrm{Te}_{\mathrm{p}}(\%)=\left(\mathrm{Te}_{\mathrm{p}} \cdot \mathrm{SPM}\right) / \mathrm{Te}_{\mathrm{T}}=\left(\mathrm{K}_{\mathrm{d}} \cdot \mathrm{SPM}\right) /\left(1+\mathrm{K}_{\mathrm{d}} \cdot \mathrm{SPM}\right)
\end{gathered}
$$

where $\mathrm{Te}_{\mathrm{p}}$ is expressed in $\mathrm{mg} \mathrm{kg}^{-1}, \mathrm{Te}_{\mathrm{d}}$ in $\mathrm{mg} \mathrm{L}^{-1}, \mathrm{Te}_{\mathrm{T}}$ in $\mathrm{mg} \mathrm{L}^{-1}$ and $\mathrm{SPM}$ in $\mathrm{kg} \mathrm{L}^{-1}$. Such experimental $\mathrm{Kd}$ can be used to estimate the dissolved Te environmental concentrations if equilibrium conditions are assumed (Filella 2011).

\subsection{Annual fluxes}

Annual fluxes of $\mathrm{Te}_{\mathrm{d}}$ (Equation 6) and $\mathrm{Te}_{\mathrm{p}}$ (Equation 7) were calculated by combining daily river discharges from the National Hydrographic Databank (DIREN) with measured $\mathrm{Te}_{\mathrm{d}}, \mathrm{Te}_{\mathrm{p}}$ and SPM concentrations ( 24-day frequency) using commonly applied equations (e.g., Meybeck et al. 1994, Meybeck and Ragu 1995, Webb et al. 1997) for discharged-weighted concentrations.

$$
\mathrm{F}_{\mathrm{Te}_{\mathrm{d}}}=\mathrm{Q}^{\prime}\left(\sum_{\mathrm{i}}^{\mathrm{n}}\left(\mathrm{Q}_{\mathrm{i}} \cdot \mathrm{Te}_{\mathrm{d}}\right) / \sum_{\mathrm{i}}^{\mathrm{n}} \mathrm{Q}_{\mathrm{i}}\right)
$$




$$
\mathrm{F}_{\mathrm{Te}_{\mathrm{p}}}=\mathrm{Q}^{\prime}\left(\sum_{\mathrm{i}}^{\mathrm{n}}\left(\mathrm{F}_{\mathrm{SPMi}} \cdot \mathrm{Te}_{\mathrm{p}}\right) / \sum_{\mathrm{i}}^{\mathrm{n}} \mathrm{Q}_{\mathrm{i}}\right) \quad \text { for } \quad \mathrm{F}_{\mathrm{SPMi}}=\mathrm{SPM}_{\mathrm{i}} \cdot \mathrm{Q}_{\mathrm{i}}
$$

where $F_{T e d}$ and $F_{T e p}$ are the dissolved and particulate discharge-weighted annual fluxes $\left(\mathrm{kg} \mathrm{y}^{-1}\right)$, $\mathrm{Q}_{\mathrm{i}}$ the daily average water discharge $\left(\mathrm{m}^{3} \mathrm{~s}^{-1}\right)$ of the sampled day (i), Q' the annual water discharge (annual mean of $\mathrm{Q}_{\mathrm{i}}$ for $\left.\mathrm{i}_{1 \rightarrow 365}\right)$ and $\mathrm{F}_{\text {SPMi }}$ the daily SPM flux $\left(\mathrm{t}^{-1}\right)$, for an annual database of size $\mathrm{n}(\mathrm{n} \leq 365$ days). Necessary unit transformations are not indicated in these equations. In addition, surface-specific annual total Te fluxes $\left(\mathrm{g} \mathrm{m}^{-2} \mathrm{y}^{-1}\right.$; i.e. normalised by the watershed area) can also be calculated to better compare and normalise fluxes between different sub-watersheds.

\subsection{Bioaccumulation factors (BAF)}

The bioaccumulation factor (BAF, Equation 8) provides information on contaminant absorption in the organism by all routes of exposure in natural conditions. It is defined as the ratio between the contaminant in the organism's tissue compared to the surrounding concentration at steady state (USEPA 2000, Arnot and Gobas 2006).

$$
B A F=\frac{C_{B}}{C_{W}}
$$

where $\mathrm{C}_{\mathrm{B}}$ is the chemical concentration (Te) in the organism (in $\mathrm{mg} \mathrm{kg}^{-1}$ ) and $\mathrm{C}_{\mathrm{W}}$ the dissolved chemical concentration $\left(\mathrm{Te}_{\mathrm{d}}\right)$ in the water $\left(\mathrm{mg} \mathrm{L}^{-1}\right)$, as in this form it shows potentially the highest bioavailability between dissolved and particulate forms (e.g., Lekhi et al. 2008).

\section{Results}

\subsection{Recent Te dynamics in the Lot-Garonne River watershed: concentrations, distribution coefficients (Kd), contamination degrees ( $I^{\prime}$ geo $)$ and annual fluxes}

The four-year survey (2014-2017) on Te in the Lot-Garonne River watershed showed similar average $\mathrm{Te}_{\mathrm{p}}$ and $\mathrm{Te}_{\mathrm{d}}$ concentrations for all sites (i.e., $\sim 50 \mu \mathrm{g} \mathrm{kg}^{-1}$ and $\sim 0.9 \mathrm{ng} \mathrm{\textrm {L } ^ { - 1 }}$ at La Réole, PortSainte-Marie, Temple and Boisse Penchot, Table 1). Out of all sites, only Riou Mort presented average 1.25-fold higher $\mathrm{Te}_{\mathrm{p}}$ concentrations (Table 1), not taking into account the anomaly in March 2017 (Figure 2e), corresponding to respectively 0.005 and 0.010 Th-normalised ratios. The temporal variations in both $\mathrm{Te}_{\mathrm{p}}$ and $\mathrm{Te} \mathrm{p}_{\mathrm{p}} / \mathrm{Th}_{\mathrm{p}}$ showed similar seasonal patterns without any clear inter-annual trend (Figure 2a-e) and were opposite to those observed for water discharge or SPM transport at all sites (Figure 2e). Dissolved Te concentrations displayed variations that were mostly parallel to those of the particulate phase especially at La Réole (Figure 2a), Port-Sainte-Marie (Figure 2b), Boisse Penchot (Figure 2d) and Riou Mort (Figure 2e). Due to these co-variations between dissolved and particulate 
concentrations, $\log _{10} \mathrm{Kd}$ values were almost constant $\left(4.7-4.8 \mathrm{~L} \mathrm{~kg}^{-1}\right)$ at all sites, without seasonal variations (Table 1).

Contamination degrees of watershed SPM in $\mathrm{Te}_{\mathrm{p}}$ showed class $1 \mathrm{I}_{\text {geo }}$ (i.e., $\mathrm{I}_{\text {geo }}<1$, unpolluted to moderately polluted) at all studied sites except for sporadic class $2 \mathrm{I}_{\text {geo }}$ values (i.e., $1 \leq \mathrm{I}_{\text {geo }}<2$, moderately polluted for Te) at Riou Mort. When the $I_{\text {geo }}$ is plotted against $\mathrm{Te}_{\mathrm{p}} / \mathrm{Th}_{\mathrm{p}}$ ratios, a unique logarithmic equation $\left(I_{\text {geo }}^{\prime}=1.443 \cdot \ln \left(\mathrm{Te}_{\mathrm{p}} / \mathrm{Th}_{\mathrm{p}}\right)+7.313\right)$ points out that SPM in the Lot-Garonne-Gironde fluvial-estuarine system exceed class 1 conditions at $\mathrm{Te}_{\mathrm{p}} / \mathrm{Th}_{\mathrm{p}}$ ratios $>0.013$. These conditions are only present in sporadic Riou Mort SPM (Figure 2e) and in deep sediments from the historical core in the hydroelectric reservoir lake of Cajarc (Gil-Díaz et al., unpublished).

Annual Te total fluxes (sum of dissolved and particulate) varied among sites and increased from the upstream sites (i.e., $\sim 3 \mathrm{~kg} \mathrm{y}^{-1}$ at Boisse Penchot and $\sim 0.2 \mathrm{~kg} \mathrm{y}^{-1}$ Riou Mort) to the most downstream sites ( $\sim 69 \mathrm{~kg} \mathrm{y}^{-1}$ at La Réole and $\sim 54 \mathrm{~kg} \mathrm{y}^{-1}$ at Port-Sainte-Marie, Table 1). Nevertheless, the data suggest high annual variability among sites, especially related with particulate fluxes, dissolved fluxes being relatively constant over the sampled years.

\subsection{Particulate Te distribution in the Gironde fluvio-estuarine system}

Within the estuarine salinity and turbidity gradients, $\mathrm{Te}_{\mathrm{p}}$ varied from $24.7 \mu \mathrm{g} \mathrm{kg}^{-1}$ to $49.3 \mu \mathrm{g} \mathrm{kg}^{-1}$ for all sampling campaigns, with Th-normalised data ranging from 0.002 to 0.005 (Figure 3a,b,c,d). In low discharge conditions $\mathrm{Te}_{\mathrm{p}}\left(40.0 \pm 4.6 \mu \mathrm{g} \mathrm{kg}^{-1}\right.$ in MGTS III and $35.7 \pm 6.1 \mu \mathrm{g} \mathrm{kg}^{-1}$ in MGTS IV; Figure $3 \mathrm{c}, \mathrm{d})$ and high discharge conditions (40.1 $\pm 3.4 \mu \mathrm{g} \mathrm{kg}^{-1}$ in MGTS II, Figure 3b) show lower averages than intermediate discharge conditions (41.0 $\pm 6.6 \mu \mathrm{g} \mathrm{kg}^{-1}$ in MGTS I, Figure 3a).

\subsection{Tellurium concentrations in whole tissue of wild oysters}

The Te concentrations in wild oysters from the La Fosse site ranged between 1.33 and $2.89 \mu \mathrm{g} \mathrm{kg}^{-1}$ dry weight (d.w.), with no particular trend at the long-term (1984-2017, Figure 4). Other oxyanionforming elements like selenium ( $\mathrm{Se}$ ) and antimony $(\mathrm{Sb})$ were also determined in this temporal series. Comparisons between $\mathrm{Te}$ and $\mathrm{Sb}$ in wild oysters of La Fosse showed parallel temporal variations (data not shown). 


\section{Discussion}

\subsection{Tellurium concentrations at the watershed scale}

Dissolved Te concentrations in the Lot-Garonne River system show medians between $0.8-1 \mathrm{ng} \mathrm{L}^{-1}$ (Table 1). Such concentrations correspond to the lower range of expected Te freshwater ranges in Europe (median $2.5 \mathrm{ng} \mathrm{L}^{-1},<5 \mathrm{ng} \mathrm{L}^{-1}$ in SW France; Salminen et al. 2005) but are clearly higher than reported concentrations in the Orinoco River (0.28 $\mathrm{ng} \mathrm{L}^{-1}$; Yoon et al. 1990) and the Mississippi River (0.53 ng $\mathrm{L}^{-1}$; Yoon et al. 1990). However, higher concentrations in freshwater have been recently reported for the Haraz and the Tajan Rivers in Iran (respectively $29 \mathrm{ng} \mathrm{L}^{-1}$ and $36 \mathrm{ng} \mathrm{L}{ }^{-1}$; Najafi et al. 2010).

Particulate Te concentrations in most studied sites presented $\mathrm{Te}_{\mathrm{p}} \sim 50 \mu \mathrm{g} \mathrm{kg}^{-1}$ and $\mathrm{Te}_{\mathrm{p}} / \mathrm{Th}_{\mathrm{p}}$ ratios of 0.005. These concentrations are within published $\mathrm{Te}_{\mathrm{p}}$ ranges in river and ocean SPM such as in the Arno River and the Venice Lagoon (i.e., 5 - $93 \mu \mathrm{g} \mathrm{kg}^{-1}$; Barghigiani et al. 1995), the East China Sea (i.e., 20 - $96 \mu \mathrm{g} \mathrm{kg}^{-1}$; Duan et al. 2014b) and the Pacific Ocean (i.e., $20-880 \mu \mathrm{g} \mathrm{kg}^{-1}$; Yoon et al. 1990). This concentration range is also in accordance with other French watersheds like that of the Rhône River were concentrations of 21.5 to $87.0 \mu \mathrm{g} \mathrm{kg}^{-1}$ have been observed in irregularly collected samples (mostly during the winter season) from 2012-2013 and 2016-2017 at Arles (Gil-Díaz et al., unpublished).

The upstream Lot River watershed hosts mineral districts enriched in $\mathrm{Zn}, \mathrm{Pb}, \mathrm{Ag}, \mathrm{U}, \mathrm{W}, \mathrm{Sn}, \mathrm{Mo}$ and Bi ores (BRGM 1978, 1983) where Te can also be associated (www.mindat.org) due to its highly chalcophile characteristics. Tellurium may be enriched in sulfides and low-temperature supergene minerals (mainly as Pb-bearing minerals, but also in sylvanite, $\mathrm{AgAuTe}_{4}$, calaverite/krennerite, $\mathrm{AuTe}_{2}$ and others; www.mindat.org). This may explain why slightly higher $\mathrm{Te}_{\mathrm{p}}$ concentrations occurred in SPM from the Riou Mort site ( $60 \mu \mathrm{g} \mathrm{kg}^{-1}$ median concentrations, i.e., median $0.010 \mathrm{Te}_{\mathrm{p}} / \mathrm{Th}_{\mathrm{p}}$ ratios) although these levels remain below the critical class $1 \mathrm{I}_{\text {geo }}$ criteria.

Sporadic high Te $\mathrm{p}_{\mathrm{p}}$ concentrations in the Riou Mort (up to 240 or $400 \mu \mathrm{g} \mathrm{kg}^{-1}$, class $2 \mathrm{I}_{\text {geo }}$, Figure 2e) suggest other processes related to remobilisation of historical sediments and smelter waste (Schroeder 1967, Filella and Rodríguez-Murillo 2017, USGS 2018). However, Te $\mathrm{p}_{\mathrm{p}}$ sporadic releases in the Riou Mort area appear relatively low compared to other anthropogenically-influenced sites showing $\mathrm{Te}_{\mathrm{p}}$ concentrations as high as $\sim 0.18-1 \mathrm{mg} \mathrm{kg}^{-1}$ in sediments from the old town of Venice (Barghigiani et al. 1995) and up to $\sim 75 \mathrm{mg} \mathrm{kg}^{-1}$ locally in harbour sediment from Baltimore (Dolor et al. 2009).

Flood events can favour high erosion rates and mobilisation of particulate trace elements from the Riou Mort watershed (topsoils and waste heaps), as already observed for $\mathrm{Cd}, \mathrm{Sb}$ and $\mathrm{Zn}$ (Coynel et al. 2007). Nevertheless, the highest $\mathrm{Te}_{\mathrm{p}}$ concentrations in the Riou Mort (and in all studied sites) occurred recurrently/systematically during low water and SPM discharges (Figure 2). This suggests (i) a common and seasonal biogeochemical behaviour of Te at the watershed scale, and (ii) no particular evidence of increasing recent anthropogenic releases. The absence of environmental anomalies due to high 
concentrations of $\mathrm{Te}$ in this early stage of massive industrial applications is consistent with predictions based on bibliographic research (Filella and Rodríguez-Murillo 2017) and experimental leaching of solar panels (Biver and Filella 2016), although one cannot exclude that longer time series in the future may reveal such anomalies.

\subsection{Seasonal patterns in Te concentrations and fluxes}

The four-year record in the river sampling sites shows parallel seasonal behaviour of $\mathrm{Te}_{\mathrm{d}}$ and $\mathrm{Te}_{\mathrm{p}}$ over time. Matching peaks of concentration variations in upstream sites (Boisse Penchot and PortSainte-Marie) and downstream sites (especially at Temple in 2015-2016 and La Réole in 2017, respectively) may reflect either a general reason at the watershed scale or the transfer of a given concentration pulse along the river continuum (from upstream to downstream), more or less attenuated by dilution effects. Noteworthy, the seasonal component of the four-year series can be estimated using the SeAsonal Factor (SAF) of non-stationary series (Gil-Díaz et al. 2018), quantifying, per studied site, the difference of monthly measurements of $\mathrm{Te}_{\mathrm{p}}$ and $\mathrm{Te}_{\mathrm{d}}$ from the average concentrations of $\mathrm{Te}_{\mathrm{p}}$ and $\mathrm{Te}_{\mathrm{d}}$ in the dataset. The obtained SAF values suggest that for the most upstream sites in each sub-watershed, namely Boisse Penchot and Port-Sainte-Marie, $\mathrm{Te}_{\mathrm{p}}$ concentrations show differences from average values with an amplitude of $\pm 10 \mu \mathrm{g} \mathrm{kg}^{-1}$ (equivalent to $\sim 20 \%$ ), with minimum values in March and maximum values in August. The more downstream sites show similar trends with some delay in May (minimum) and September (maximum), and lower amplitudes ( $10 \%)$. This apparent seasonal pattern is less defined for $\mathrm{Te}_{\mathrm{d}}$ concentrations, but minimum (in March) and maximum (July-August) values occur synchronously at all sites and are in phase with the $\mathrm{Te}_{\mathrm{p}}$ variations of the upstream sites.

Such parallel, seasonal behaviour of both dissolved and particular phases is uncommon as generally particulate concentrations do not show such obvious changes as dissolved concentrations. In fact, clear seasonal patterns in the dissolved phase, with low winter concentrations and high summer values, also occur in the Lot-Garonne River system for Sb (Gil-Díaz et al. 2018), As (Masson et al. 2007), Mo, V (Masson 2007) and Cs (Gil-Díaz et al. unpublished), but not in the particulate concentrations. Similar variation patterns also occur for Te, As, Mo, Se and V dissolved concentrations in alkaline stream waters of the Mediterranean region (Salminen et al. 2005). Like V, Sb, As and Mo, Te is an oxyanion considered to be soluble at pH 7 (Filella and Rodríguez-Murillo 2017) forming hydroxide species (i.e. $\mathrm{TeO}_{2}(\mathrm{OH})^{-}$ and $\mathrm{Te}(\mathrm{OH})_{6}$ ) or oxyanion species $\left(\mathrm{TeO}_{3}{ }^{2-}\right.$ and $\left.\mathrm{TeO}_{4}{ }^{2-}\right)$. Seasonal variations in dissolved $\mathrm{V}$ and $\mathrm{Mo}$ in the Mississippi River (Shiller 1997) were mainly explained by the weathering rate from source silicate rocks (Shiller and Mao 2000) and secondarily by in situ redox pumping (Moore 1994) and oxygen depletion conditions in bottom waters and sediments (Shiller and Mao 1999). Likewise, previous studies in the Lot-Garonne watershed have explained dissolved As seasonal variations by reduction of As(V) 
to more soluble As(III) and/or As-bearing mineral dissolution by microorganisms at water temperatures $>15^{\circ} \mathrm{C}$ (Masson et al. 2007), being less intense for Sb (Gil-Díaz et al. 2018).

Despite the shared seasonal behaviour, all these oxyanions seem to have different properties or expected behaviours, making it difficult to attribute their common variations to a single mechanism. In fact, reducing processes causing As reduction and increasing its solubility should reduce V(V) species (more mobile) to V(IV) species, which are actually subtracted from the dissolved phase by sorption to SPM (Shiller and Mao 1999, 2000). Likewise, dissolution of Fe/Mn oxyhydroxides (abiotic or biologically-mediated) could increase dissolved $\mathrm{As}$, $\mathrm{Sb}$, Mo and $\mathrm{V}$ concentrations due to common mineral sources and high affinity for these mineral phases (Salminen et al. 2005). Other biogeochemical parameters measured in the water column (i.e., dissolved organic carbon - DOC, particulate organic carbon - POC and chlorophyll-a - Chl-a) do not match the seasonal behaviour observed in the aforementioned oxyanions and differ in concentrations between sampling sites, suggesting that processes related to primary production as a potential release mechanism can be ruled out.

The fact that all these elements show potentially common mineral sources in the watershed (Salminen et al. 2005), and that Cs also shows the same aforementioned seasonal variability suggests that Te watershed behaviour may be related to chemical weathering processes with increased rate in latesummer. In fact, Cs is a cation with only one oxidation state $(+1)$, typically found in granites from $\mathrm{K}$ substitutions in K-feldspars and micas as well as within fluorine deposits (www.mindat.org). Its seasonal pattern is most evident at Boisse Penchot and Riou Mort, showing 4-fold higher $\mathrm{Cs}_{\mathrm{p}}$ concentrations than the Garonne River sites (Gil-Díaz et al. unpublished), which points to Cs release by weathering of rocks and minerals, consistent with strong Cs enrichments in Hercynian leucogranite intrusions and Cs-rich fluorine mineral ores in the Massif Central (BRGM 1978, BRGM 1983, Salminen et al. 2005). Efficient sorption of Te to Fe-oxides like ferrihydrite (Hayes et al. 2011) and clay minerals (Hayes et al. 2012) in SPM appears as likely, given its suspected high particle affinity (Whitehead et al. 1988, Wu et al. 2014). Furthermore, $\mathrm{Te}(\mathrm{IV})$ and $\mathrm{Te}(\mathrm{VI})$ seem to equally adsorb to $\mathrm{Fe}(\mathrm{III})$ hydroxydes and illite mineral phases in soils affected by abandoned mine areas (Harada and Takahashi 2009, Qin et al. 2017), thus a change in their redox speciation would not imply different redox-related seasonal sorption behaviours. Accordingly, the above considerations and the constant $\mathrm{Kd}$ along the different seasons, suggest rapid equilibration of Te between the dissolved and the particulate phases, after the supposed $\mathrm{Te}_{\mathrm{d}}$ release due to intensification of weathering processes during summer.

Annual $\mathrm{Te}_{\mathrm{d}}$ fluxes are relatively constant at each site over the 4-year period. In contrast, $\mathrm{Te}_{\mathrm{p}}$ fluxes show higher variability and mostly reflected general SPM transport at the watershed scale. Surfacespecific total (dissolved + particulate) Te fluxes are similar for most sites with $1.21 \pm 1.14 \mathrm{~g} \mathrm{~m}^{-2} \mathrm{y}^{-1}$ at La Réole, $1.17 \pm 1.32 \mathrm{~g} \mathrm{~m}^{-2} \mathrm{y}^{-1}$ at Port-Sainte-Marie and $1.11 \pm 0.67 \mathrm{~g} \mathrm{~m}^{-2} \mathrm{y}^{-1}$ at Riou Mort. The Temple site shows two-fold lower surface-specific total Te fluxes of $0.54 \pm 0.30 \mathrm{~g} \mathrm{~m}^{-2} \mathrm{y}^{-1}$. This observation may 
suggest that Te fluxes at Temple have their main origins in the upstream watershed (Boisse Penchot and Riou Mort), and that rocks (i.e., limestones and marls) and soils in the central/lower part of the Lot River watershed are poor in mobile/soluble Te forms. Given that (i) the upstream Garonne River watershed (upstream of Port-Sainte-Marie) constitutes $81 \%$ of the total Garonne River watershed area (integrated at La Réole), and (ii) both sites have comparable surface-specific total Te fluxes, we can suggest that most of the Te arriving to the Gironde Estuary comes from the Garonne River watershed upstream from Port-Sainte-Marie.

\subsection{Tellurium solid/liquid partitioning}

In general, partitioning coefficients $(\mathrm{Kd})$ indicate element affinity for the particulate phase, i.e., the higher the Kd, the less easily the element will be transported in the dissolved phase. Such definition relies on two hypotheses (Filella 2011): (1) the operationally-defined distinction between "dissolved" and "particulate" phases (filtration cut-off), and (2) the existence of a C-type isotherm (i.e., the ratio between dissolved and particulate concentrations is the same at any concentration, which usually occurs for low concentrations; Limousin et al. 2007). Moreover, Kd generally depends on the abundance and speciation of the element, the equilibrium time of the interaction, particle nature and concentration, complexing ligand concentrations and biological activity (Ciffroy et al. 2009).

In contrast to the few existing studies on Te in fluvial-estuarine systems (van der Sloot et al. 1985, Wu et al. 2014, Duan et al. 2014a), this is the first paper presenting natural $\mathrm{Kd}$ values for $\mathrm{Te}\left(\log _{10} \mathrm{Kd}\right.$ 4.7-4.8 $\mathrm{L} \mathrm{kg}^{-1}$, Table 1). The observed freshwater $\mathrm{Kd}$ values are in accordance with experimentally determined Te partition coefficients for higher SPM concentrations (i.e., $\log _{10} \mathrm{Kd} \sim 4.9 \mathrm{~L} \mathrm{~kg}^{-1}$ in $100 \mathrm{mg}$ $\mathrm{L}^{-1} \mathrm{SPM}$ and $\log _{10} \mathrm{Kd} \sim 5.3 \mathrm{~L} \mathrm{~kg}^{-1}$ in $\left.1000 \mathrm{mg} \mathrm{L}^{-1} \mathrm{SPM}\right)$. The latter were obtained from sorption batch experiments at constant temperature $\left(21.1 \pm 0.4^{\circ} \mathrm{C}\right)$ with dissolved $(<0.2 \mu \mathrm{m})$ concentrations of up to 5 $\mu \mathrm{g} \mathrm{L}{ }^{-1} \mathrm{Te}(\mathrm{VI})$, variable SPM concentrations (i.e., $100 \mathrm{mg} \mathrm{L}^{-1}$ and $1000 \mathrm{mg} \mathrm{L}^{-1} \mathrm{SPM}$ ) and equilibration times of $48 \mathrm{~h}$ (Gil-Díaz et al., unpublished). These results suggest that both inherited (natural) and excess (adsorbed) Te compounds have similar solid/liquid partitioning in turbidity ranges potentially occurring in natural aquatic systems (Figure 5). This information is important for oceanographic and radiological models, where Kd values are not always determined in the environment, thus assuming similarities with experimental Kd (IAEA 2004).

Furthermore, the aforementioned batch sorption experiments in seawater suggest that $\log _{10} \mathrm{Kd}$ values are similar to those in freshwater (Figure 5). Therefore, natural or experimental Kd values can provide an estimate of natural $\mathrm{Te}_{\mathrm{d}}$ concentrations from measured $\mathrm{Te}_{\mathrm{p}}$, even in complex matrices like those along the salinity and turbidity gradients in the Gironde Estuary. These $\mathrm{Kd}$ values can be applied to environmental $\mathrm{Te}_{\mathrm{p}}$ concentrations assuming a C-type isotherm for both $100 \mathrm{mg} \mathrm{L}^{-1}$ and $1000 \mathrm{mg} \mathrm{L}^{-1}$ 
SPM given that experimental isotherms clearly showed that the environmental Te concentrations fall within the linear range of the general Langmuir isotherm (Gil-Díaz et al., unpublished).

Based on this approach, the estimated $\mathrm{Te}_{\mathrm{d}}$ for the high-salinity range in the Gironde Estuary and covering a wide range of turbidity (taking the average $\log _{10} \mathrm{Kd}$ of $4.96 \mathrm{~L} \mathrm{~kg}^{-1}$ for both 100 and $1000 \mathrm{mg}$ $\mathrm{L}^{-1}$ in the Gironde Estuary) ranged from 0.27 to $0.52 \mathrm{ng} \mathrm{L}^{-1}$ for $\mathrm{S}>20$ for all sampled hydrological conditions. Such concentrations are consistent with a cluster of typical values reported for oceanic and coastal waters published before 1990's ( $<1 \mathrm{ng} \mathrm{L}^{-1}$; Filella 2013, Biver et al. 2015). However, clearly higher $\mathrm{Te}_{\mathrm{d}}$ seawater concentrations have been recently reported for the East China Sea coastal waters (1 - $9 \mathrm{ng} \mathrm{L} \mathrm{L}^{-1}$; Wu et al. 2014), in seawater near the Chinese cities of Zhuhai and Dalian (10 - $32 \mathrm{ng} \mathrm{L}^{-1}$; Huang and Hu 2008) and in the Caspian Sea (28 ng L ${ }^{-1}$; Najafi et al. 2010). Further work is necessary to explain these concentration differences.

\subsection{Tellurium estuarine reactivity}

Compared to typical river values, the freshwater reaches of the estuary show an initial $\sim 30 \%$ decrease in $\mathrm{Te}_{\mathrm{p}}$, especially during low discharge conditions (i.e., long residence times of water and SPM within the estuary), in the presence of high SPM (Figure $3 \mathrm{c}, \mathrm{d}$ ). A less intense decrease occurs for intermediate discharge conditions (Figure 3a), whereas during flood conditions $\mathrm{Te}_{\mathrm{p}}$ are constant throughout the salinity gradient (MGTS II; Figure $3 b$ ). In the MTZ, both $\mathrm{Te}_{\mathrm{p}}$ and $\mathrm{Th}_{\mathrm{p}}$ vary similarly, decreasing $\mathrm{Th}_{\mathrm{p}}$ suggesting the presence of coarser particles (e.g. Larrose et al. 2010). These observations suggest that $\mathrm{Te}_{\mathrm{p}}$ depend on variations in particle size, consistent with the observed efficient equilibration between the dissolved and the particulate phases. In the absence of a potential mixing endmember strongly characterised by Te-depleted particles, the minimum $\mathrm{Te}_{\mathrm{p}} / \mathrm{Th}_{\mathrm{p}}$ ratios in the MTZ during low- to intermediate discharge were probably influenced by dissolution/mobilisation processes driven by intense mineralisation of particulate organic matter in this part of the estuary (Abril et al. 1999; Etcheber et al. 2007). In fact, intense organic matter mineralisation in the upstream part of the MTZ could locally release $\mathrm{Te}_{\mathrm{d}}$, which would then be re-adsorbed in other mineral phases such as $\mathrm{Fe} / \mathrm{Mn}$ oxides and clays (Duan et al. 2014b). This process would suggest a potential exchange of Te carrier phases within the MTZ. In the downstream part of the MTZ and over the main part of the salinity range, $\mathrm{Te}_{\mathrm{p}}$ nearly doubles to $\sim 40 \mu \mathrm{g} \mathrm{kg}^{-1}$ with $\mathrm{Te}_{\mathrm{p}} / \mathrm{Th}_{\mathrm{p}}$ increasing to $\sim 0.0034$ (Figure 3). These increases may be attributed to equilibration between the dissolved and particulate phases, implying re-adsorption of dissolved Te onto the particles in the MTZ. This observation is in accordance with the constant experimental Kd values (Figure 5) in contrasting salinities (i.e., $\mathrm{S}=0$ and $\mathrm{S}=32$ ) and $\mathrm{SPM}$ variations (i.e., over two orders of magnitude). In fact, $\mathrm{Te}_{\mathrm{d}}$ varies from $10 \%$ of total Te in $\sim 100 \mathrm{mg} \mathrm{L}^{-1} \mathrm{SPM}$ to $<1 \% \mathrm{in} \sim 1000 \mathrm{mg} \mathrm{L}^{-1} \mathrm{SPM}$. The observed non-conservative behaviour in the Gironde Estuary is consistent with that in the 
Changiiang Estuary turbidity gradient (i.e., $20 \leq \mathrm{SPM} \leq 100 \mathrm{mg} \mathrm{L}^{-1}$ ), reporting no correlation between $\mathrm{Te}_{\mathrm{d}}$ concentrations and salinity ( $\mathrm{S}>25$; Wu et al. 2014).

The simultaneous decreases of $\mathrm{Te}_{\mathrm{p}}$ and $\mathrm{Th}_{\mathrm{p}}$ in the high salinity range of the estuary mouth under low discharge conditions (Figure $3 \mathrm{c}, \mathrm{d}$ ) probably reflect the increasing presence of marine organic matter as supported by increasing POC values (from $1.20 \%$ to $1.66 \%$ in drought conditions, and $1.50 \%$ to $2.00 \%$ in intermediate conditions; data not shown). In fact, sediment characteristics (i.e., grain-size and total organic carbon content) are expected to largely control Te distribution in coastal environments (Duan et al. 2014b).

\subsection{Tellurium historical record in wild oysters}

Long-term records (1984-2017) of Te in wild oysters at the Gironde Estuary mouth show stable values with no specific trend. These levels are similar to those in shellfish from other French coastal areas (2-3 $\mu \mathrm{g} \mathrm{kg}^{-1}$; Guerin et al. 2011) and from wild oysters from the Arcachon Bay $(1.18 \pm 0.52 \mu \mathrm{g}$ $\mathrm{kg}^{-1}$ in 2014, N=20; Gil-Díaz et al., unpublished). Nevertheless, higher concentrations have been observed in wild oysters from the Bilbao Estuary $\left(3.48 \pm 1.39 \mu \mathrm{g} \mathrm{kg}^{-1}\right.$ in 2014, N=20; Gil-Díaz et al., unpublished), an estuary currently highly populated and known for its past metal pollution due to historical industrial activities (Belzunce et al. 2001, Borja et al. 2006). These observations, together with the observed high particulate affinity of Te, could suggest that current anthropogenic Te discharges to fluvial systems could be buffered in highly turbid continent-ocean transition systems such as the Gironde Estuary, decreasing the uptake of Te as an emerging contaminant in coastal organisms. Therefore, the potential influence of current Te anthropogenic releases could be studied in biomonitoring organisms, like wild oysters, from continent-ocean systems presenting lower SPM content.

The absence of anomalous Te concentrations in the Gironde Estuary oysters and the fact that there is no clear temporal trend is the opposite of what occurs for other anthropogenically released metals in these oysters (e.g. Cd, Ag, Pt; Lanceleur et al. 2011b, Abdou et al. 2016). This observation may suggest that potential emerging Te sources in the watershed have not caused measurable Te accumulation in the Gironde oysters either due to relatively low emissions or limited bioconcentration. Based on estimated $\mathrm{Te}_{\mathrm{d}}$ of $0.46 \mathrm{ng} \mathrm{L}^{-1}$ in the estuary mouth $(15<\mathrm{S}<25)$, estimated BAFs for Te in oysters range from 2900 to 6300 , i.e. are similar in magnitude to those of Se $(3600-8200$, for dissolved Se concentrations of $\left.\sim 0.31 \mu \mathrm{g} \mathrm{L}^{-1}\right)$. These BAF in the Gironde oysters are similar in magnitude as those determined for $\mathrm{Pt}$ $\left(\sim 10^{3}\right.$; Abdou et al. 2016) and much lower than known BAFs for $\mathrm{Cd}$ and $\mathrm{Ag}\left(\sim 10^{6}\right.$; Lanceleur et al. 2011b). Nevertheless, research on Te and Se organotropism in wild oysters from the Gironde Estuary mouth (pool of $\mathrm{N}=5$ in 2014) point out different biological roles between both assumed geochemical homologues as Te and Se in the digestive gland account for $\sim 50 \%$ of the total soft tissue content, whereas 
in the gills Se accounts for $\sim 30 \%$ and Te for $\sim 14 \%$ (Gil-Díaz et al. unpublished). Therefore, one may assume a mixed Te uptake in filter feeders combining direct and trophic pathways.

Despite the yet unknown biological role of Te (Chasteen et al. 2009) studies in other aquatic environments have observed interactions between Te contents in seawater and organisms. In fact, historical records of $\mathrm{Te}_{\mathrm{p}}$ in a sediment core from the East China Sea (i.e., enrichment factors-EF $\sim 2$ at $\sim 20 \mathrm{~cm}$ depth corresponding to 1989) are thought to be explained by frequent phytoplankton development from red tides during the late 1980's, enriching the sediment with both Te and Se (Duan et al. 2014b). Likewise, marine phytoplankton and crustaceans interact directly with $\mathrm{Te}_{\mathrm{d}}$ radiotracers (i.e., concentrations of $\sim 1 \mu \mathrm{g} \mathrm{L}^{-1}$ ), with instantaneous Te precipitation in elemental form within phytoplankton cultures but no apparent direct trophic transfer/bioaccumulation (Nolan et al. 1991). This ability of microorganisms to produce elemental $\mathrm{Te}$ is used in the nanotechnology industry for $\mathrm{Te}$ applications, yet for concentrations much higher than environmental levels ( $\mathrm{mg} \mathrm{L}^{-1}$ range; Baesman et al. 2007). After biological uptake, Te shows intracellular reactivity, as it can damage cells and be biomethylated (̌̌ezanka and Sigler 2008, Chasteen et al. 2009). All these observations suggest that one cannot exclude physiological effects of $\mathrm{Te}$ in oysters and other seafood, albeit at much higher environmental levels than currently encountered. Further research is necessary to (i) clarify and evaluate the respective importance of both uptake pathways, and (ii) understand the fate and effects of $\mathrm{Te}$ in organisms, particularly in comparison with Se, a known essential micronutrient and geochemical peer

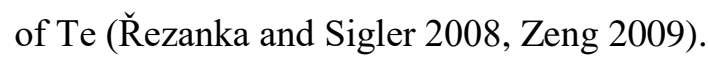

The authors declare no conflicts of interest

\section{Acknowledgements}

This study is a scientific contribution to the French National Project AMORAD (ANR-11-RSNR0002) from the National Research Agency, allocated in the framework programme "Investments for the Future" and was partially funded by the ANR Program TWINRIVERS (ANR-11-IS56-0003) and the 
FEDER Aquitaine-1999-Z0061. The authors greatly acknowledge support from 'l'Agence de l'Eau Adour-Garonne", the European Project SCHEMA (EU FP7-OCEAN 2013.2-Grant Agreement 614002) and the RNO/ROCCH tissue bank, with Anne GROUHEL as the current manager of the ROCCH. We are also grateful to the crew of the French Oceanographic R/V Thalia (sampling campaigns MGTS I doi 10.17600/14008300; MGTS II doi 10.17600/15009300; MGTS III doi 10.17600/15010600 and MGTS IV).

\section{References}

Abdou, M., Schäfer, J., Cobelo-García, A., Neira, P., Petit, J. C., Auger, D., Chiffoleau, J.-F., Blanc, G. (2016). Past and present platinum contamination of a major European fluvial-estuarine system: Insights from river sediments and estuarine oysters. Marine Chemistry, 185, 104-110.

Abril, G., Etcheber, H., Le Hir, P., Bassoullet, P., Boutier, B., Frankignoulle, M. (1999). Oxic/anoxic oscillations and organic carbon mineralization in an estuarine maximum turbidity zone (The Gironde, France). Limnology and Oceanography, 44(5), 1304-1315.

Allen, G. P., Salomon, J. C., Bassoullet, P., Du Penhoat, Y., De Grandpre, C. (1980). Effects of tides on mixing and suspended sediment transport in macrotidal estuaries. Sedimentary Geology, 26(1-3), 6990.

Arnot, J.A., Gobas, F.A.P.C. (2006). A review of bioconcentration factor (BCF) and bioaccumulation factor (BAF) assessments for organic chemicals in aquatic organisms. Environmental Reviews, 14: 257297

Audry, S., Schäfer, J., Blanc, G., Jouanneau, J. M. (2004). Fifty-year sedimentary record of heavy metal pollution $(\mathrm{Cd}, \mathrm{Zn}, \mathrm{Cu}, \mathrm{Pb}$ ) in the Lot River reservoirs (France). Environmental Pollution, 132(3), 413426.

Ba, L. A., Döring, M., Jamier, V., Jacob, C. (2010). Tellurium: an element with great biological potency and potential. Organic \& biomolecular chemistry, 8(19), 4203-4216.

Baesman, S. M., Bullen, T. D., Dewald, J., Zhang, D., Curran, S., Islam, F. S., Beveridge, T.J., Oremland, R. S. (2007). Formation of tellurium nanocrystals during anaerobic growth of bacteria that use Te oxyanions as respiratory electron acceptors. Applied and environmental microbiology, 73(7), 2135-2143.

Barghigiani, C., D'Ulivo, A., Lampugnani, L., Pellegrini, G., Romboli, L., Zamboni, R. (1995, May). Distribution of $\mathrm{As}, \mathrm{Sb}, \mathrm{Se}, \mathrm{Te}$ and $\mathrm{Hg}$ in some sediments of the Venice Lagoon. In International Conference on Chemistry and the Mediterranean Sea. Taranto, Italy (p. 139).

Belzile, N., Chen, Y. W. (2015). Tellurium in the environment: A critical review focused on natural waters, soils, sediments and airborne particles. Applied Geochemistry, 63, 83-92.

Belzunce, M. J., Solaun, O., Franco, J., Valencia, V., Borja, Á. (2001). Accumulation of organic matter, heavy metals and organic compounds in surface sediments along the Nervión Estuary (Northern Spain). Marine Pollution Bulletin, 42(12), 1407-1411. 
Biver, M., Quentel, F., Filella, M. (2015). Direct determination of tellurium and its redox speciation at the low nanogram level in natural waters by catalytic cathodic stripping voltammetry. Talanta, 144, 1007-1013.

Biver, M., Filella, M. (2016). Bulk dissolution rates of cadmium and bismuth tellurides as a function of pH, temperature and dissolved oxygen. Environmental Science \& Technology, 50(9), 4675-4681

Borja, Á., Muxika, I., Franco, J. (2006). Long-term recovery of soft-bottom benthos following urban and industrial sewage treatment in the Nervión estuary (southern Bay of Biscay). Marine Ecology Progress Series, 313, 43-55.

Bureau de Recherches Géologiques et Minières (BRGM) (1978). Carte des gîtes minéraux de la France à 1/500000e, feuille de LYON, Service Géologique National.

Bureau de Recherches Géologiques et Minières (BRGM) (1983). Carte des gîtes minéraux de la France à 1/500000e, feuille de BORDEAUX, Service Géologique National.

Castaing, P., Allen, G. P. (1981). Mechanisms controlling seaward escape of suspended sediment from the Gironde: a macrotidal estuary in France. Marine Geology, 40(1-2), 101-118.

Castaing, P., Jouanneau, J. M. (1979). Temps de résidence des eaux et des suspensions dans l'estuaire de la Gironde. Journal Recherche Océanographie IV, 41-52.

Chasteen, T. G., Fuentes, D. E., Tantaleán, J. C., Vásquez, C. C. (2009). Tellurite: history, oxidative stress, and molecular mechanisms of resistance. FEMS Microbiology Reviews, 33(4), 820-832.

Chen, Z., Xu, G. D., Chen, S., Zhang, J. H., Wang, M. M. (2014). Hydrothermal synthesized nanostructure $\mathrm{Bi}-\mathrm{Sb}-\mathrm{Te}$ thermoelectric materials. Journal of Alloys and Compounds, 588, 384-387.

Ciffroy, P., Durrieu, G., Garnier, J. M. (2009). Probabilistic distribution coefficients (Kds) in freshwater for radioisotopes of $\mathrm{Ag}, \mathrm{Am}, \mathrm{Ba}, \mathrm{Be}, \mathrm{Ce}, \mathrm{Co}, \mathrm{Cs}, \mathrm{I}, \mathrm{Mn}, \mathrm{Pu}, \mathrm{Ra}, \mathrm{Ru}, \mathrm{Sb}, \mathrm{Sr}$ and Th-implications for uncertainty analysis of models simulating the transport of radionuclides in rivers. Journal of environmental radioactivity, 100(9), 785-794.

Cobelo-García, A., Filella, M., Croot, P., Frazzoli, C., Du Laing, G., Ospina-Alvarez, N., Rauch, S., Salaun, P., Schäfer, J., Zimmermann, S. (2015). COST action TD1407: network on technology-critical elements (NOTICE) - from environmental processes to human health threats. Environmental Science and Pollution Research, 22(19), 15188-15194.

Coynel, A., Schäfer, J., Blanc, G., Bossy, C. (2007). Scenario of particulate trace metal and metalloid transport during a major flood event inferred from transient geochemical signals. Applied Geochemistry, 22(4), 821-836.

Council Regulation (EC) 2006/11/EC of 15 February 2006 on pollution caused by certain dangerous substances discharged into the aquatic environment of the Community [2006] OJ L64/52

Daskalakis, K.D., O’Connor, T.P., Crecelius, E.A. (1997). Evaluation of digestion procedures for determining silver in mussels and oysters. Environmental Science and Technology, 31: 2303-2306

DIREN - National Hydrographic Databank [internet]. Ministère de l'Écologie, du Développement Durable et de l'Énergie, 2015 [cited 16 December 2015]. Available from: http://www.hydro.eaufrance.fr/

Dolor, M. K., Helz, G. R., McDonough, W. F. (2009). Sediment profiles of less commonly determined elements measured by Laser Ablation ICP-MS. Marine pollution bulletin, 59(4-7), 182-192. 
Doxaran, D., Froidefond, J. M., Castaing, P., Babin, M. (2009). Dynamics of the turbidity maximum zone in a macrotidal estuary (the Gironde, France): Observations from field and MODIS satellite data. Estuarine, Coastal and Shelf Science, 81(3), 321-332.

Duan, L. Q., Song, J. M., Yuan, H. M., Li, X. G., Li, N., Ma, J. K. (2014a). Distribution, chemical speciation and source of trace elements in surface sediments of the Changjiang Estuary. Environmental Earth Sciences, 72(8), 3193-3204.

Duan, L. Q., Song, J. M., Yuan, H. M., Li, X. G., Li, N., Ma, J. (2014b). Selenium and tellurium fractionation, enrichment, sources and chronological reconstruction in the East China Sea. Estuarine, Coastal and Shelf Science, 143, 48-57.

Etcheber, H., Taillez, A., Abril, G., Garnier, J., Servais, P., Moatar, F., Commarieu, M. V. (2007). Particulate organic carbon in the estuarine turbidity maxima of the Gironde, Loire and Seine estuaries: origin and lability. Hydrobiologia, 588(1), 245-259.

Filella, M. (2011). Antimony interactions with heterogeneous complexants in waters, sediments and soils: a review of data obtained in bulk samples. Earth-science reviews, 107(3-4), 325-341.

Filella, M. (2013). Food for thought: a critical overview of current practical and conceptual challenges in trace element analysis in natural waters. Water 5, 1152-1171

Filella, M., Rodríguez-Murillo, J. C. (2017). Less-studied TCE: are their environmental concentrations increasing due to their use in new technologies? Chemosphere, 182, 605-616.

Filella, M., Rodushkin, I. (2018). A concise guide for the determination of less-studied technologycritical elements $(\mathrm{Nb}, \mathrm{Ta}, \mathrm{Ga}, \mathrm{In}, \mathrm{Ge}, \mathrm{Te})$ by inductively coupled plasma mass spectrometry in environmental samples. Spectrochimica Acta Part B: Atomic Spectroscopy, 141, 80-84.

Gil-Díaz, T., Schäfer, J., Pougnet, F., Abdou, M., Dutruch, L., Eyrolle-Boyer, F., Coynel, A., Blanc, G. (2016). Distribution and geochemical behaviour of antimony in the Gironde estuary: A first qualitative approach to regional nuclear accident scenarios. Marine Chemistry, 185, 65-73.

Gil-Díaz, T., Schäfer, J., Coynel, A., Bossy, C., Dutruch, L., Blanc, G (2018). Antimony in the LotGaronne river system: a 14-year record of solid-liquid partitioning and fluxes. Environmental Chemistry. DOI:10.1071/EN17188

Guérin, T., Chekri, R., Vastel, C., Sirot, V., Volatier, J. L., Leblanc, J. C., Noël, L. (2011). Determination of 20 trace elements in fish and other seafood from the French market. Food Chemistry, 127(3), 934942.

Harada, T., \& Takahashi, Y. (2009). Origin of the difference in the distribution behavior of tellurium and selenium in a soil-water system. Geochimica et Cosmochimica Acta, 72(5), 1281-1294.

Hayes, S., Foster, A. L., Balistrieri, L. S. (2011, December). Examining tellurium geochemistry using laboratory-based sorption studies and spectroscopic investigation of natural samples. In AGU Fall Meeting Abstracts.

Hayes, S. M., Foster, A., Balistrieri, L. (2012, November). Tellurium speciation in surficial weathering environments. In 2012 GSA Annual Meeting in Charlotte.

Huang, C., Hu, B. (2008). Speciation of inorganic tellurium from seawater by ICP-MS following magnetic SPE separation and preconcentration. J. Sep. Sci. 31, 760-767 
IAEA, I. (2004). Sediment distribution coefficients and concentration factors for biota in the marine environment. International Atomic Energy Agency: Vienna, Austria.

Jouanneau, J.M., Latouche, C., 1981. The Gironde Estuary. Contributions to Sedimentology. vol. 10, pp. 1-115 (Stuttgart)

Kabata-Pendias, A. (2011). Trace Elements in Soils and Plants. CRC Press, Taylor and Francis Group.

Krachler, M., Shotyk, W. (2004). Natural and anthropogenic enrichments of molybdenum, thorium and uranium in a complete peat bog profile, Jura Mountains, Switzerland. Journal of Environmental Monitoring 6, 418-426.

Lanceleur, L., Schäfer, J., Bossy, C., Coynel, A., Larrose, A., Masson, M., Blanc, G. (2011a). Silver fluxes to the Gironde Estuary-Eleven years (1999-2009) of monitoring at the watershed scale. Applied geochemistry, 26(5), 797-808.

Lanceleur, L., Schäfer, J., Chiffoleau, J. F., Blanc, G., Auger, D., Renault, S., Baudrimont, M., Audry, S. (2011b). Long-term records of cadmium and silver contamination in sediments and oysters from the Gironde fluvial-estuarine continuum-Evidence of changing silver sources. Chemosphere, 85(8), 12991305.

Lapaquellerie, Y., Maillet, N., Jouanneau, J.-M., Coakley, J.P., Latouche, C., 1996. Flux de matières en suspension et de cadmium dans le Lot. Hydroécol. Appl. 8, 173-191.

Larrose, A., Coynel, A., Schäfer, J., Blanc, G., Massé, L., Maneux, E. (2010). Assessing the current state of the Gironde Estuary by mapping priority contaminant distribution and risk potential in surface sediment. Applied Geochemistry, 25(12), 1912-1923.

Latouche, C. (1992). La pollution par le cadmium des huîtres sauvages de l'Estuaire de la Gironde. Origine. Mécanismes responsables de la fixation du cadmium. Ichtyophysiol. Acta, 15, 139-152.

Leal, J. J., Narro-García, R., Desirena, H., Marconi, J. D., Rodríguez, E., Linganna, K., De la Rosa, E. (2015). Spectroscopic properties of tellurite glasses co-doped with $\mathrm{Er}^{3+}$ and $\mathrm{Yb}^{3+}$. Journal of Luminescence, 162, 72-80.

Lee, D. S., Edmond, J. M. (1985). Tellurium species in seawater. Nature, 313(6005), 782.

Lee, M., Bae, W., Chung, J., Jung, H. S., Shim, H. (2008). Seasonal and spatial characteristics of seawater and sediment at Youngil bay, Southeast Coast of Korea. Marine Pollution Bulletin, 57(6-12), 325-334.

Lekhi, P., Cassis, D., Pearce, C. M., Ebell, N., Maldonado, M. T., Orians, K. J. (2008). Role of dissolved and particulate cadmium in the accumulation of cadmium in cultured oysters (Crassostrea gigas). Science of the Total Environment, 393(2-3), 309-325.

Lerat-Hardy, A., Coynel, A., Dutruch, L., Pereto, C., Bossy, C., Gil-Díaz, T., Capdeville, M.J., Blanc, G., Schäfer, J. (2019). Rare Earth Element fluxes over 15 years into a major European Estuary (GaronneGironde, SW France): Hospital effluents as a chance of increasing gadolinium anomalies. Science of the Total Environment, 656, 409-420.

Limousin, G., Gaudet, J. P., Charlet, L., Szenknect, S., Barthes, V., Krimissa, M. (2007). Sorption isotherms: a review on physical bases, modeling and measurement. Applied Geochemistry, 22(2), 249275. 
Mahdy, M. A., Mahdy, I. A., El Zawawi, I. K. (2015). Characterization of $\mathrm{Pb}_{24} \mathrm{Te}_{76}$ quantum dot thin film synthesized by inert gas condensation. Spectrochimica Acta Part A: Molecular and Biomolecular Spectroscopy, 134, 302-309.

Masson, M. (2007). Sources et transferts métalliques dans le bassin versant de la Gironde: Réactivité et mécanismes géochimiques dans l'estuaire fluvial de la Gironde (Doctoral dissertation, Bordeaux 1).

Masson, M., Schäfer, J., Blanc, G., Anschutz, P. (2007). Seasonal variations and annual fluxes of arsenic in the Garonne, Dordogne and Isle Rivers, France. Science of the total environment, 373(1), 196-207.

Meybeck, M., Ragu, A. (1995). river Discharges to the Oceans. An Assessment of Suspended Solids, Major Ions, and Nutrients. (UNEP: Nairobi)

Meybeck, M., Pasco, A., \& Ragu, A. (1994). Etablissement des flux polluants dans les rivières : pourquoi, comment et à quel prix. 4eme Rencontres de l'Agence Régionale pour l'environnement. In Provence-Alpes-Côte d'Azur. Colloque scientifique sur les charges polluantes véhiculées par les fleuves et les rivières en Méditerranée.

Millour, S., Noël, L., Chekri, R., Vastel, C., Kadar, A., Sirot, V., Leblanc, J.-C., Guérin, T. (2012). Strontium, silver, tin, iron, tellurium, gallium, germanium, barium and vanadium levels in foodstuffs from the Second French Total Diet Study. Journal of Food Composition and Analysis, 25(2), 108-129.

Moore, J. N. (1994). Contaminant mobilization resulting from redox pumping in a metal-contaminated river-reservoir system. Advances in Chemistry.

Müller G (1969). Index of geoaccumulation in sediments of the Rhine river. The Journal of Geology 2, $108-118$.

Najafi, N.M., Tavakoli, H., Alizadeh, R., Seidi, S. (2010). Speciation and determination of ultra trace amounts of inorganic tellurium in environmental water samples by dispersive liquid-liquid microextraction and electrothermal atomic absorption spectrometry. Analytica Chimica Acta, 670, 1823

Nolan, C., Whitehead, N., Teyssie, J. L. (1991). Tellurium — speciation in seawater and accumulation by marine phytoplankton and crustaceans. Journal of Environmental radioactivity, 13(3), 217-233.

Qin, H.-B, Takeichi, Y., Nitani, H., Terada, Y., Takahashi, Y. (2017). Tellurium distribution and speciation in contaminated soils from abandoned mine tailings: comparison with selenium. Environmental Science \& Technology, 51(11), 6027-6035.

Řezanka, T., Sigler, K. (2008). Biologically active compounds of semi-metals. In Studies in natural products chemistry (Vol. 35, pp. 835-921). Elsevier.

Salminen, R., Batista, M.J., Bidovec, M., Demetriades, A., De Vivo, B., De Vos, W., Duris, M., Gilucis, A., et al. (2005). Geochemical Atlas of Europe (FOREGS). Part 1 - Background Information, Methodology and Maps.

Salomon, J. N. (2002). L'inondation dans la basse vallée de la Garonne et l'estuaire de la Gironde lors de la. Géomorphologie: relief, processus, environnement, 8(2), 127-134.

Schäfer, J., Blanc, G., Lapaquellerie, Y., Maillet, N., Maneux, E., Etcheber, H., (2002). Ten-YearObservation of the Gironde Fluvial System: Fluxes of Suspended Matter, Particulate Organic Carbon and Cadmium. Mar. Chem. 79; 229 
Schroeder, H. A., Buckman, J., Balassa, J. J. (1967). Abnormal trace elements in man: tellurium. Journal of Clinical Epidemiology, 20(3), 147-161.

Shiller, A. M. (1997). Dissolved trace elements in the Mississippi River: seasonal, interannual, and decadal variability. Geochimica et Cosmochimica Acta, 61(20), 4321-4330.

Shiller, A. M., Mao, L. (1999). Dissolved vanadium on the Louisiana Shelf: effect of oxygen depletion. Continental Shelf Research, 19(8), 1007-1020.

Shiller, A. M., Mao, L. (2000). Dissolved vanadium in rivers: effects of silicate weathering. Chemical Geology, 165(1-2), 13-22.

Sottolichio, A., Castaing, P. (1999). A synthesis on seasonal dynamics of highly-concentrated structures in the Gironde estuary. Comptes Rendus de l'Académie des Sciences-Series IIA-Earth and Planetary Science, 329(11), 795-800.

Sung, W. (1995). Some observations on surface partitioning of $\mathrm{Cd}, \mathrm{Cu}$ and $\mathrm{Zn}$ in estuaries. Environ. Sci. Technol, 29; 1303

Turner, R. J., Borghese, R., Zannoni, D. (2012). Microbial processing of tellurium as a tool in biotechnology. Biotechnology advances, 30(5), 954-963.

U.S. Environmental Protection Agency (2000). Methods for measuring the toxicity and bioaccumulation of sediment-associated contaminants with freshwater invertebrates. Second edition. EPA 600/R-99/064

U.S. Environmental Protection Agency (Revised in 2007). Determination of Trace Metals By SW-846. Method 6020A. Inductively Coupled Plasma-Mass Spectrometry. EPA, Connecticut

USGS (2018). U.S. Geological Survey, Mineral Commodity Summaries, Tellurium. [cited 01 August 2018]. Available from:

van der Sloot, H. A., Hoede, D., Wijkstra, J., Duinker, J. C., Nolting, R. F. (1985). Anionic species of $\mathrm{V}, \mathrm{As}, \mathrm{Se}, \mathrm{Mo}, \mathrm{Sb}, \mathrm{Te}$ and $\mathrm{W}$ in the Scheldt and Rhine estuaries and the Southern Bight (North Sea). Estuarine, Coastal and Shelf Science, 21(5), 633-651.

Wang, X., Guan, W. (2012). Large-scale synthesis of flower-like Te nanocrystals with uniform branches by a surfactant-assisted method. Nanoscience Methods, 1(1), 86-92.

Webb, B.W., Phillips, J.M., Walling, D.E., Littlewood, I.G., Watts, C., Leeks, G.J.L. (1997). Load estimation methodologies for British river and their relevance to the LOIS RACS (R) program. The Science of the Total Environment 194-195, 379-389.

Whitehead, N. E., Ballestra, S., Holm, E., Huynh-Ngoc, L. (1988). Chernobyl radionuclides in shellfish. Journal of environmental radioactivity, 7(2), 107-121.

Wu, X., Song, J., Li, X. (2014). Occurrence and distribution of dissolved tellurium in Changjiang River estuary. Chinese journal of oceanology and limnology, 32(2), 444-454.

Yang, G., Zheng, J., Tagami, K., Uchida, S. (2014). Soil-to-crop transfer factors of tellurium. Chemosphere, 111: 554-559

Yoon, B. M., Shim, S. C., Pyun, H. C., Lee, D. S. (1990). Hydride generation atomic absorption determination of tellurium species in environmental samples with in situ concentration in a graphite furnace. Analytical Sciences, 6(4), 561-566. 
Zeng, H. (2009). Selenium as an essential micronutrient: roles in cell cycle and apoptosis. Molecules, 14(3), 1263-1278.

Zhou, Y., Li, L., Tan, Q., Li, J. F. (2014). Thermoelectric properties of Pb-doped bismuth telluride thin films deposited by magnetron sputtering. Journal of Alloys and Compounds, 590, 362-367. 


\section{Figures}

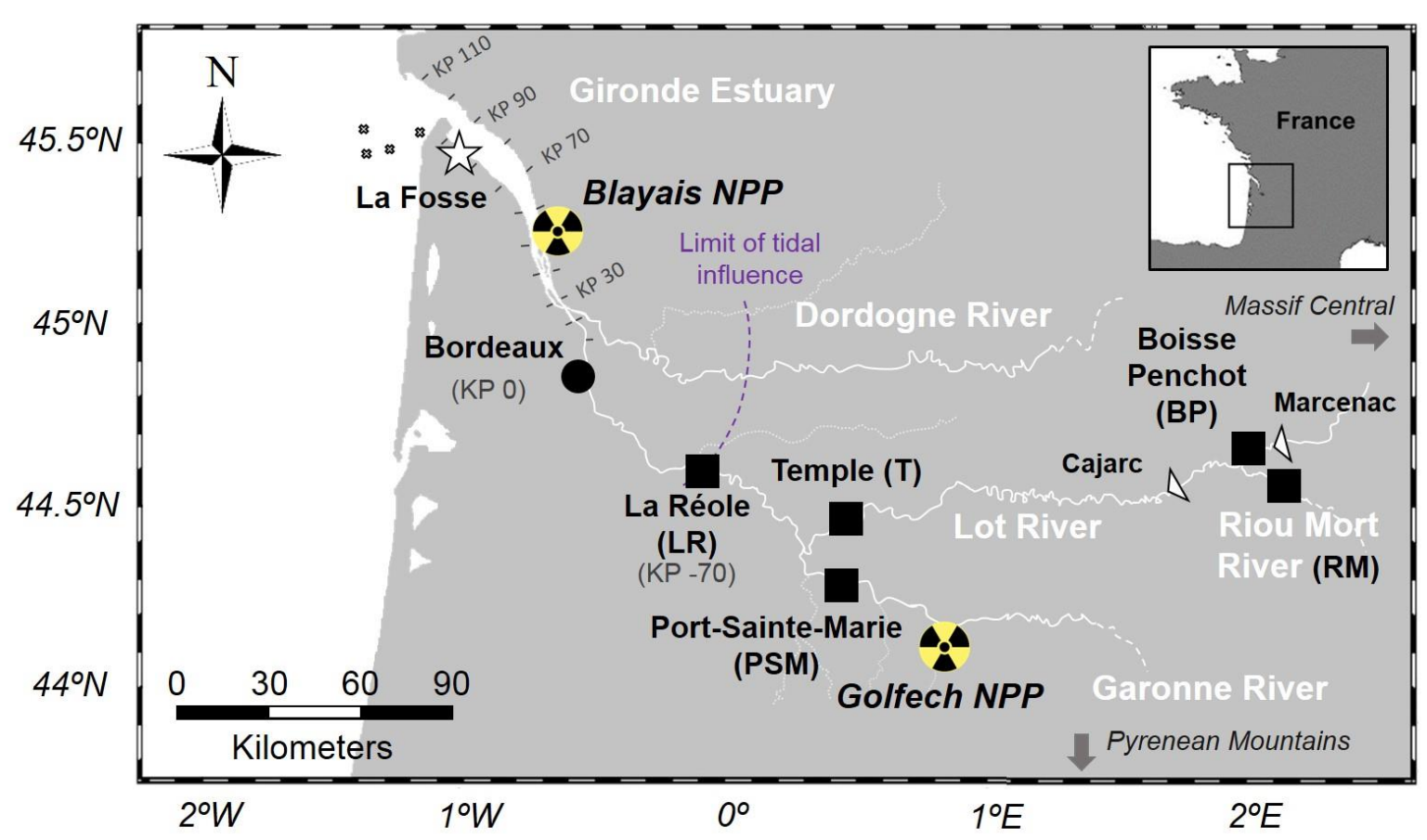

Figure 1. Location of sampling sites in the Lot-Garonne-Gironde fluvial estuarine system: upstream sediment cores at Cajarc and Marcenac water reservoirs in the Lot River (triangles), 4-year monitoring sites at RM, BP, T, PSM and LR (squares), coastal ocean sampling points (MGTS IV, empty crosses) and oyster sampling site (La Fosse, RNO/ROCCH, star). Locations of nuclear power plants (NPP) are also shown. 

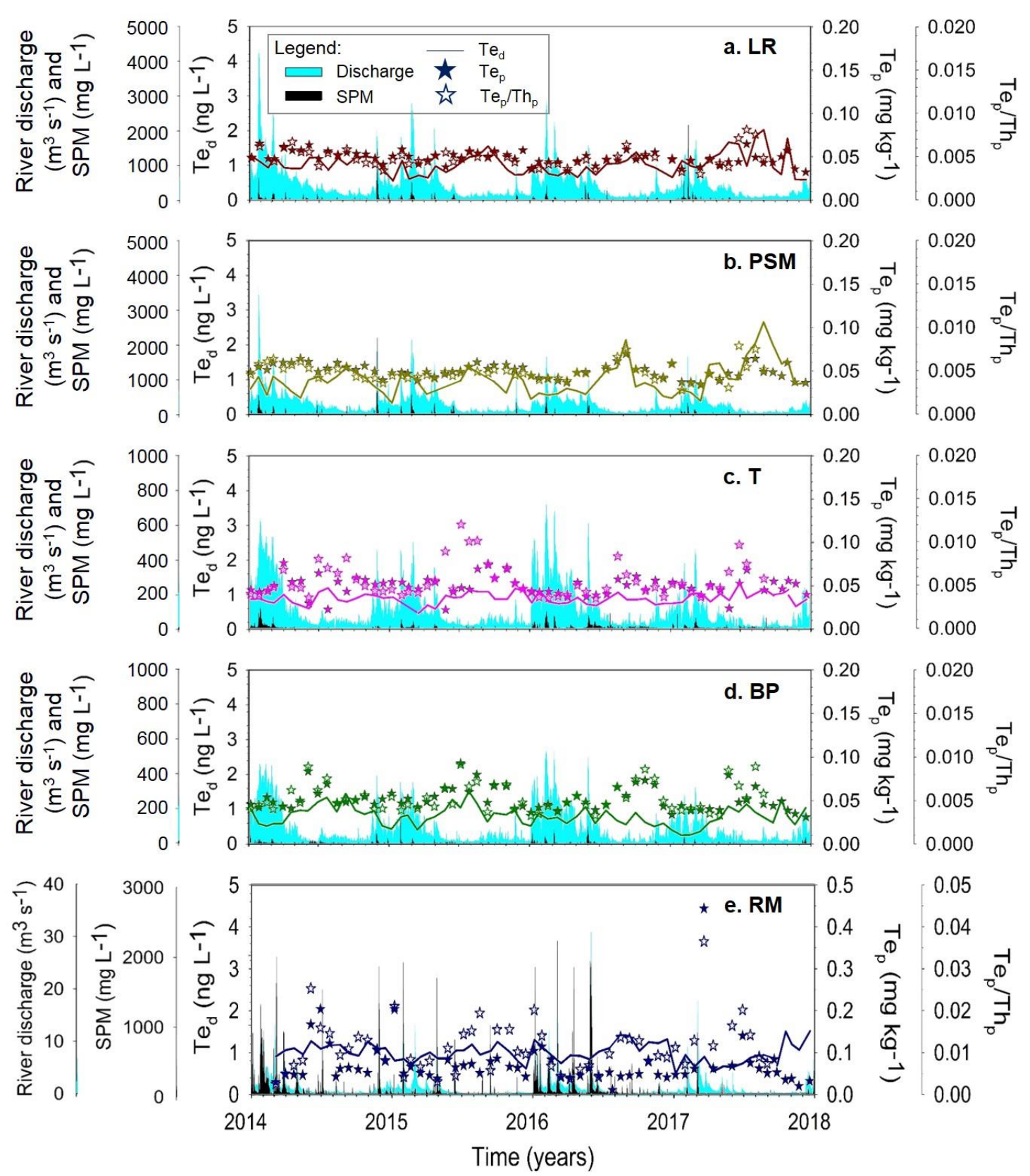

Figure 2. Four-year follow-up (2014-2017) of particulate $\mathrm{Te}\left(\mathrm{Te}_{\mathrm{p}}\right.$, filled stars) and dissolved $\mathrm{Te}\left(\mathrm{Te}_{\mathrm{d}}\right.$, lines) in the Lot-Garonne fluvial system: La Réole (LR, a), Port-Sainte-Marie (PSM, b), Temple (T, c), Boisse Penchot (BP, d) and Riou Mort (RM, e). Thorium-normalised particulate Te concentrations $\left(\mathrm{Te}_{\mathrm{p}} / \mathrm{Th}_{\mathrm{p}}\right.$, empty stars), daily water discharges (cyan bar charts) and suspended particulate matter concentrations (SPM, black bar charts) are also shown. 

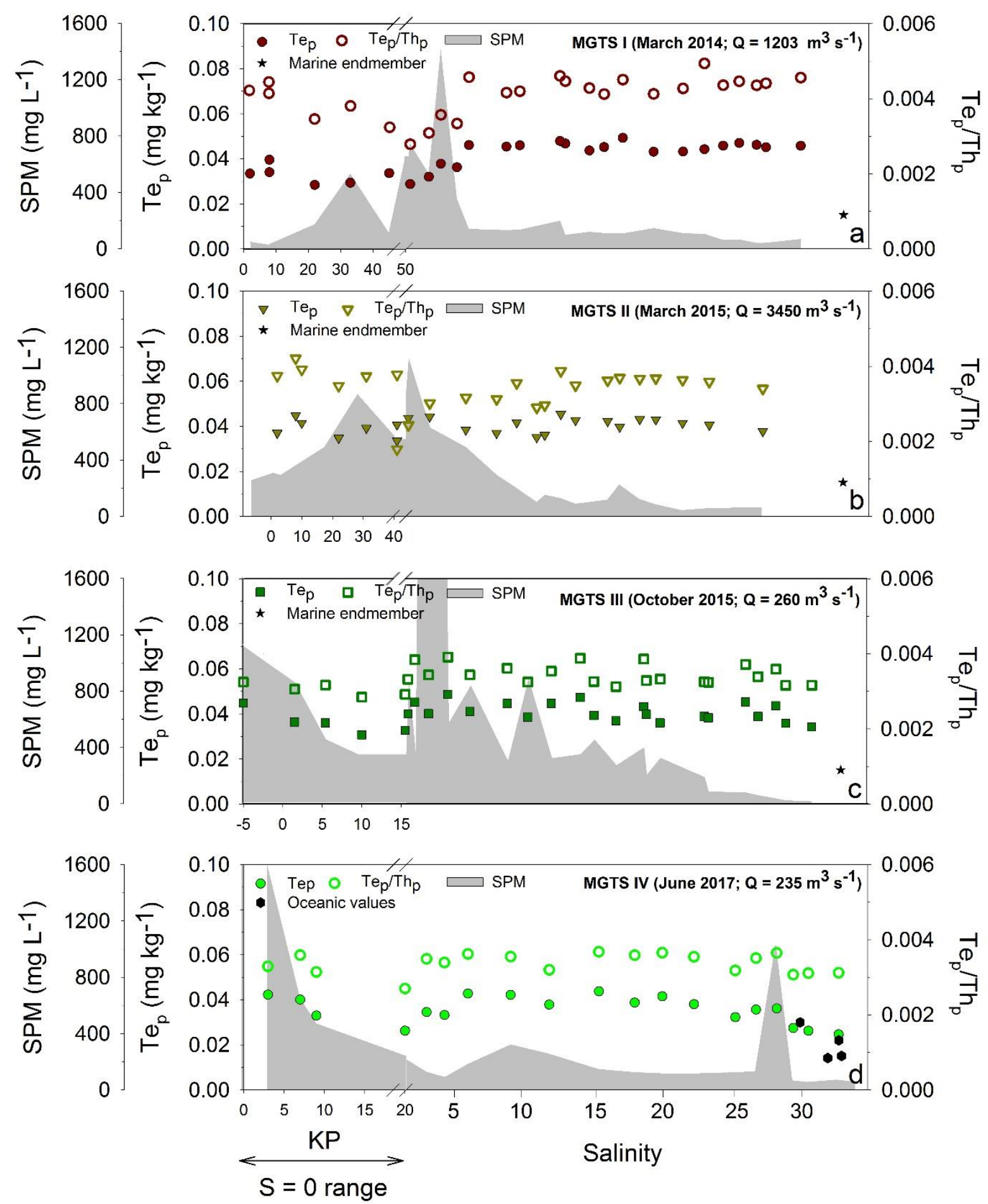

Figure 3. Tellurium distribution along the salinity and turbidity gradients of the Gironde Estuary during four sampling campaigns (MGTS): (a) intermediate discharge (MGTS I), (b) high discharge (MGTS II), and two low discharge conditions (c, MGTS III) and (d, MGTS IV). Values in the $\mathrm{S}=0$ salinity range are expressed in kilometric points (KP) for spatial resolution. Suspended particulate matter (SPM) concentrations (shaded grey), particulate Te concentrations ( $\mathrm{Te}_{\mathrm{p}}$, filled symbols), thorium-normalised particulate $\mathrm{Te}$ concentrations $\left(\mathrm{Te}_{\mathrm{p}} / \mathrm{Th}_{\mathrm{p}}\right.$, empty symbols), and the marine endmember $\mathrm{Te}_{\mathrm{p}}$ (stars) are also shown. 


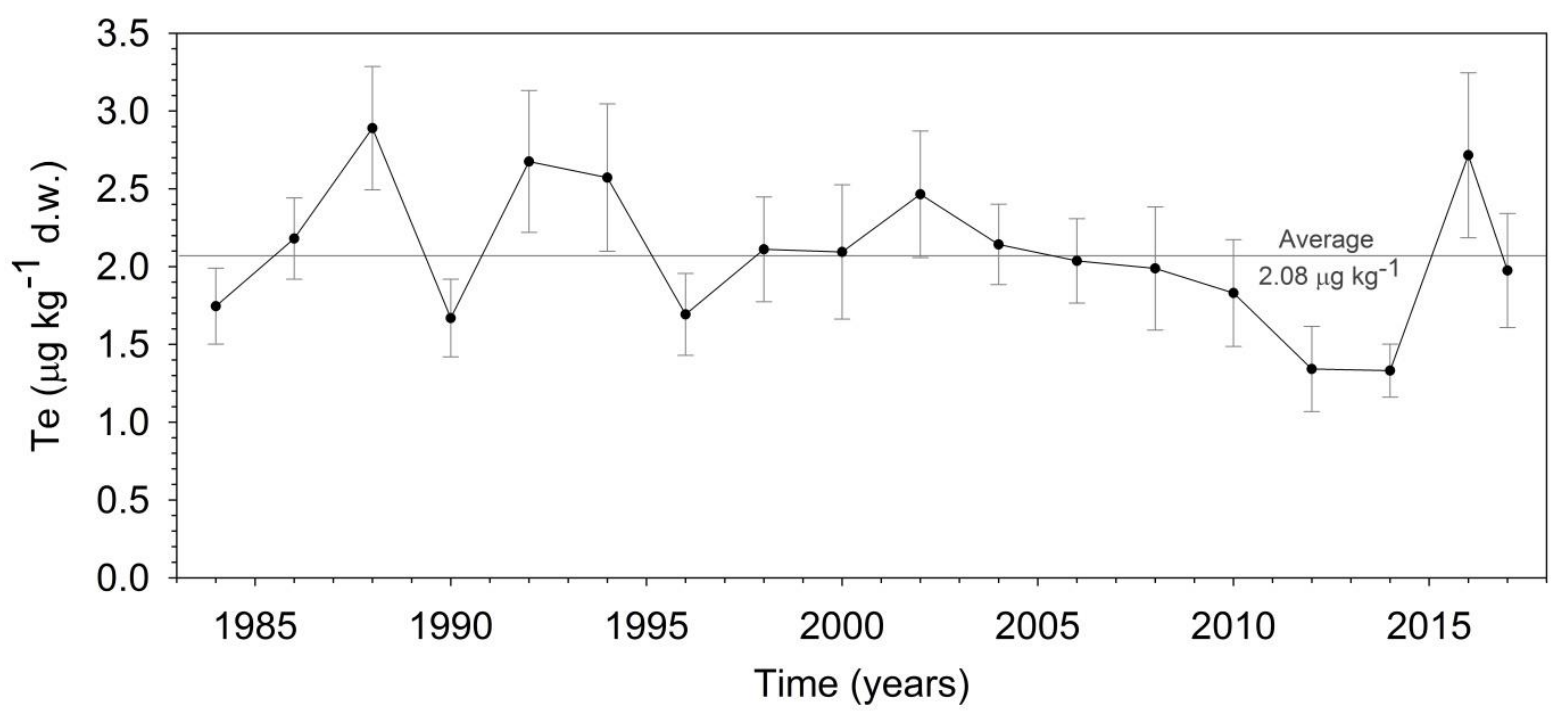

Figure 4. Long-term record (1984-2017) of Te in soft tissue from pools of winter (February/March) wild oysters Crassostrea gigas from the French National Mussel Watch Program RNO/ROCCH at La Fosse site.

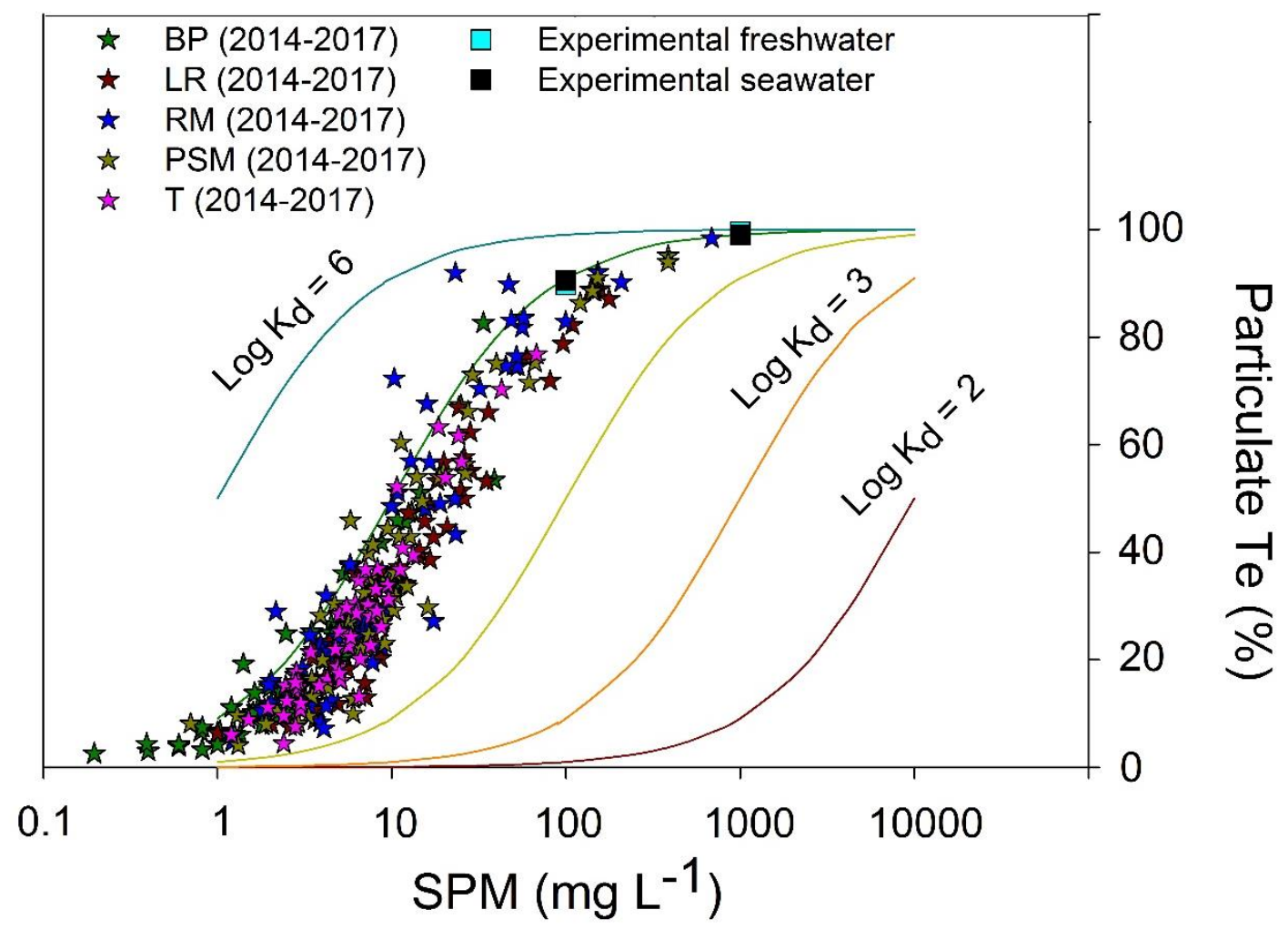

Figure 5. Solid/liquid partitioning (Kd) of Te vs suspended particulate matter (SPM) concentrations at five sites in the Lot-Garonne River system (stars): La Réole (LR), Port-Sainte-Marie (PSM), Temple (T), Boisse Penchot (BP) and Riou Mort (RM). Estimated Kd values at equilibrium after 48h sorption batch experiments in freshwater and seawater conditions for $100 \mathrm{mg} \mathrm{L}^{-1}$ and $1000 \mathrm{mg} \mathrm{L}^{-1} \mathrm{SPM}$ (GilDíaz et al. unpublished) are also shown. 
Table 1. Physical-chemical parameters and Te concentrations. Overview on water temperature, conductivity, $\mathrm{pH}$ and redox potential (Eh), river discharge $(\mathrm{Q})$, suspended particulate matter $(\mathrm{SPM})$ concentrations, dissolved $\left(\mathrm{Te}_{\mathrm{d}}\right)$ and particulate $\left(\mathrm{Te}_{\mathrm{p}}\right) \mathrm{Te}$ concentrations as well as thorium-normalized $\mathrm{Te} \mathrm{p}_{\mathrm{p}}$ concentrations $\left(\mathrm{Te}_{\mathrm{p}} / \mathrm{Th}_{\mathrm{p}}\right.$ ), solid/liquid distribution coefficients $\left(\log _{10} \mathrm{~K}_{\mathrm{d}}\right.$ ) and $\mathrm{Te}_{\mathrm{d}}$ ("d") and $\mathrm{Te}_{\mathrm{p}}$ ("p") fluxes from 2014 to 2017 at five sampling sites in the LotGaronne River system: La Réole (LR), Port-Sainte-Marie (PSM), Temple (T), Boisse Penchot (BP) and Riou Mort (RM). Generally, mean values \pm standard deviations (SD), with minimum and maximum (in brackets) and median values are given per site.

\begin{tabular}{|c|c|c|c|c|c|c|c|c|c|c|c|}
\hline Site & $\begin{array}{l}\text { Water temp. } \\
\left({ }^{\circ} \mathrm{C}\right)\end{array}$ & $\begin{array}{l}\text { Conduct. } \\
\left(\mu \mathrm{S} \mathrm{cm}^{-1}\right)\end{array}$ & pH & $\begin{array}{l}\text { Eh } \\
(\mathrm{mV})\end{array}$ & $\begin{array}{l}\mathbf{Q} \\
\left(\mathrm{m}^{3} \mathrm{~s}^{-1}\right)\end{array}$ & $\begin{array}{l}\text { SPM } \\
\left(\mathrm{mg} \mathrm{L}^{-1}\right)\end{array}$ & $\begin{array}{l}\text { Te }_{d} \\
\left(n g L^{-1}\right)\end{array}$ & $\begin{array}{l}\mathrm{Te}_{\mathrm{p}} \\
\left(\mu \mathrm{gg}^{-1}\right)\end{array}$ & $\mathrm{Te}_{\mathrm{p}} / \mathrm{Th}_{\mathrm{p}}$ & $\begin{array}{l}\log _{10} K_{d} \\
\left(\mathrm{~L} \mathrm{~kg}^{-1}\right)\end{array}$ & $\begin{array}{l}\text { Te }_{\mathrm{d}} \text { and } \mathrm{Te}_{\mathrm{p}} \\
\text { fluxes }\left(\mathrm{kg} \mathrm{y}^{-1}\right)\end{array}$ \\
\hline & $\begin{array}{l}\text { Mean } \pm \text { SD } \\
{[\text { min. }- \text { max.] }} \\
\text { Median }\end{array}$ & $\begin{array}{l}\text { Mean } \pm \text { SD } \\
\text { [min. - max.] } \\
\text { Median }\end{array}$ & $\begin{array}{l}\text { Mean } \pm \text { SD } \\
{[\text { min. }- \text { max. }]} \\
\text { Median }\end{array}$ & $\begin{array}{l}\text { Mean } \pm \text { SD } \\
\text { [min. }- \text { max.] } \\
\text { Median }\end{array}$ & $\begin{array}{l}\text { Mean } \pm \text { SD } \\
\text { [min. - max.] } \\
\text { Median }\end{array}$ & $\begin{array}{l}\text { Mean } \pm \text { SD } \\
{[\min .-\max .]} \\
\text { Median }\end{array}$ & $\begin{array}{l}\text { Mean } \pm \text { SD } \\
\text { [min. - max.] } \\
\text { Median }\end{array}$ & $\begin{array}{l}\text { Mean } \pm \text { SD } \\
\text { [min. - max.] } \\
\text { Median }\end{array}$ & $\begin{array}{l}\text { Mean } \pm \text { SD } \\
\text { [min. }- \text { max.] } \\
\text { Median }\end{array}$ & $\begin{array}{l}\text { Mean } \pm \text { SD } \\
{[\text { min. }- \text { max. }]} \\
\text { Median }\end{array}$ & $\begin{array}{l}\text { Mean } \pm \text { SD } \\
{[\text { min. - max.] }}\end{array}$ \\
\hline LR & $\begin{array}{l}15.4 \pm 6.5 \\
{[5.3-28.1]} \\
15.0\end{array}$ & $\begin{array}{l}288 \pm 23 \\
{[238-346]} \\
286\end{array}$ & $\begin{array}{l}8.27 \pm 0.27 \\
{[7.73-9.40]} \\
8.23\end{array}$ & $\begin{array}{l}130 \pm 43 \\
{[43-247]} \\
126\end{array}$ & $\begin{array}{l}476 \pm 465 \\
{[79-4500]} \\
321\end{array}$ & $\begin{array}{l}32 \pm 92 \\
{[0-2180]} \\
13\end{array}$ & $\begin{array}{l}1.04 \pm 0.32 \\
{[0.56-2.02]} \\
0.98\end{array}$ & $\begin{array}{l}48.2 \pm 7.5 \\
{[32.0-65.0]} \\
47.7\end{array}$ & $\begin{array}{l}0.0048 \pm 0.0010 \\
{[0.0030-0.0081]} \\
0.0047\end{array}$ & $\begin{array}{l}4.68 \pm 0.13 \\
{[4.32-4.96]} \\
4.68\end{array}$ & $\begin{array}{l}\mathrm{d}: 15.0 \pm 4.4 \\
{[12.1-21.5]} \\
\mathrm{p}: 53.9 \pm 60.7 \\
{[6.7-140]}\end{array}$ \\
\hline PSM & $\begin{array}{l}15.1 \pm 6.3 \\
{[5.7-26.5]} \\
14.7\end{array}$ & $\begin{array}{l}291 \pm 32 \\
{[222-374]} \\
289\end{array}$ & $\begin{array}{l}8.24 \pm 0.21 \\
{[7.41-8.72]} \\
8.26\end{array}$ & $\begin{array}{l}138 \pm 41 \\
{[52-264]} \\
134\end{array}$ & $\begin{array}{l}333 \pm 312 \\
{[58-3720]} \\
246\end{array}$ & $\begin{array}{l}28 \pm 86 \\
{[0-2320]} \\
10\end{array}$ & $\begin{array}{l}1.00 \pm 0.47 \\
{[0.33-2.66]} \\
0.91\end{array}$ & $\begin{array}{l}49.9 \pm 8.1 \\
{[34.9-69.7]} \\
49.2\end{array}$ & $\begin{array}{l}0.0048 \pm 0.0010 \\
{[0.0027-0.0079]} \\
0.0047\end{array}$ & $\begin{array}{l}4.74 \pm 0.18 \\
{[4.27-5.16]} \\
4.73\end{array}$ & $\begin{array}{l}\mathrm{d}: 8.05 \pm 3.44 \\
{[5.09-13.0]} \\
\mathrm{p}: 46.0 \pm 58.2 \\
{[7.6-131]}\end{array}$ \\
\hline $\mathbf{T}$ & $\begin{array}{l}16.1 \pm 6.9 \\
{[5.8-28.7]} \\
16.4\end{array}$ & $\begin{array}{l}256 \pm 47 \\
{[148-454]} \\
251\end{array}$ & $\begin{array}{l}8.13 \pm 0.39 \\
{[7.16-9.31]} \\
8.09\end{array}$ & $\begin{array}{l}143 \pm 49 \\
{[44-297]} \\
140\end{array}$ & $\begin{array}{l}120 \pm 124 \\
{[11-762]} \\
68\end{array}$ & $\begin{array}{l}12 \pm 12 \\
{[0-143]} \\
8\end{array}$ & $\begin{array}{l}0.89 \pm 0.17 \\
{[0.46-1.33]} \\
0.87\end{array}$ & $\begin{array}{l}49.8 \pm 10.9 \\
{[22.6-76.8]} \\
50.4\end{array}$ & $\begin{array}{l}0.0055 \pm 0.0019 \\
{[0.0035-0.0120]} \\
0.0048\end{array}$ & $\begin{array}{l}.74 \pm 0.13 \\
{[4.28-5.01]} \\
4.76\end{array}$ & $\begin{array}{l}\mathrm{d}: 3.00 \pm 1.19 \\
{[1.72-4.02]} \\
\mathrm{p}: 2.77 \pm 2.18 \\
{[0.43-5.63]}\end{array}$ \\
\hline BP & $\begin{array}{l}13.4 \pm 6.1 \\
{[5.4-27.0]} \\
12.6\end{array}$ & $\begin{array}{l}174 \pm 170 \\
{[93-1470]} \\
149\end{array}$ & $\begin{array}{l}8.15 \pm 0.33 \\
{[7.51-8.94]} \\
8.14\end{array}$ & $\begin{array}{l}146 \pm 48 \\
{[30-286]} \\
140\end{array}$ & $\begin{array}{l}95 \pm 100 \\
{[9-590]} \\
52\end{array}$ & $\begin{array}{l}5 \pm 9 \\
{[0-146]} \\
3\end{array}$ & $\begin{array}{l}0.81 \pm 0.28 \\
{[0.26-1.52]} \\
0.80\end{array}$ & $\begin{array}{l}51.7 \pm 13.1 \\
{[31.0-93.0]} \\
48.3\end{array}$ & $\begin{array}{l}0.0053 \pm 0.0016 \\
{[0.0032-0.0091]} \\
0.0048\end{array}$ & $\begin{array}{l}4.82 \pm 0.16 \\
{[4.47-5.23]} \\
4.83\end{array}$ & $\begin{array}{l}\mathrm{d}: 2.14 \pm 0.65 \\
{[1.51-2.74]} \\
\mathrm{p}: 0.91 \pm 0.35 \\
{[0.45-1.20]}\end{array}$ \\
\hline RM & $\begin{array}{l}14.4 \pm 5.8 \\
{[4.7-27.2]} \\
14.2\end{array}$ & $\begin{array}{l}904 \pm 423 \\
{[276-2150]} \\
827\end{array}$ & $\begin{array}{l}8.18 \pm 0.30 \\
{[7.58-8.96]} \\
8.13\end{array}$ & $\begin{array}{l}151 \pm 41 \\
{[61-237]} \\
143\end{array}$ & $\begin{array}{l}1 \pm 2 \\
{[0-31]} \\
1\end{array}$ & $\begin{array}{l}72 \pm 220 \\
{[0-2810]} \\
13\end{array}$ & $\begin{array}{l}1.01 \pm 0.23 \\
{[0.50-1.51]} \\
1.00\end{array}$ & $\begin{array}{l}67.5 \pm 37.0 \\
{[20.3-204]} \\
60.1\end{array}$ & $\begin{array}{l}0.0107 \pm 0.0051 \\
{[0.0025-0.0365]} \\
0.0100\end{array}$ & $\begin{array}{l}4.81 \pm 0.25 \\
{[4.28-5.69]} \\
4.81\end{array}$ & $\begin{array}{l}\text { d: } 0.04 \pm 0.02 \\
{[0.02-0.06]} \\
\text { p: } 0.13 \pm 0.11 \\
{[0.03-0.28]}\end{array}$ \\
\hline
\end{tabular}


